IZA DP No. 10383

The Impact of Quality Rating and Improvement Systems on Families' Child Care Choices and the Supply of Child Care Labor

Chris M. Herbst

November 2016 


\title{
The Impact of Quality Rating and Improvement Systems on Families' Child Care Choices and the Supply of Child Care Labor
}

\author{
Chris M. Herbst \\ Arizona State University \\ and IZA
}

\section{Discussion Paper No. 10383 \\ November 2016}

\author{
IZA \\ P.O. Box 7240 \\ 53072 Bonn \\ Germany \\ Phone: +49-228-3894-0 \\ Fax:+49-228-3894-180 \\ E-mail: iza@iza.org
}

Any opinions expressed here are those of the author(s) and not those of IZA. Research published in this series may include views on policy, but the institute itself takes no institutional policy positions. The IZA research network is committed to the IZA Guiding Principles of Research Integrity.

The Institute for the Study of Labor (IZA) in Bonn is a local and virtual international research center and a place of communication between science, politics and business. IZA is an independent nonprofit organization supported by Deutsche Post Foundation. The center is associated with the University of Bonn and offers a stimulating research environment through its international network, workshops and conferences, data service, project support, research visits and doctoral program. IZA engages in (i) original and internationally competitive research in all fields of labor economics, (ii) development of policy concepts, and (iii) dissemination of research results and concepts to the interested public.

IZA Discussion Papers often represent preliminary work and are circulated to encourage discussion. Citation of such a paper should account for its provisional character. A revised version may be available directly from the author. 


\section{ABSTRACT \\ The Impact of Quality Rating and Improvement Systems on Families' Child Care Choices and the Supply of Child Care Labor ${ }^{1}$}

Quality Rating and Improvement Systems (QRIS) are increasingly deployed by states to monitor and improve the quality of non-parental child care settings. By making information on program quality accessible to the public, QRIS attempts to alter parental preferences for quality-related attributes and encourage competition between providers. This paper draws on a variety of datasets to empirically characterize the way in which families and providers respond to the enactment of QRIS. Specifically, it exploits the differential timing in states' QRIS roll-out to examine two sets of outcomes: (i) families' child care choices and maternal employment and (ii) the supply and compensation of child care labor. Estimates from difference-in-differences models reveal several noteworthy findings. First, although QRIS induces families to shift from parental to non-parental care, economically disadvantaged families are more likely to use informal care, while their advantaged counterparts are more likely to use formal care. Second, QRIS increases the supply of high-skilled labor, particularly within the center-based sector. Third, all but the most highly-skilled child care workers experience rising compensation levels but also greater turnover. Finally, states that administer a wage compensation program alongside their QRIS experience larger increases in child care supply and compensation as well as lower turnover rates than states operating a QRIS in isolation.

JEL Classification: J13, J21, J22, J24, J3

Keywords: child care, quality rating and improvement systems

Corresponding author:

Chris M. Herbst

School of Public Affairs

Arizona State University

411 N. Central Ave., Suite 420

Phoenix, AZ 85004-0687

USA

E-mail: chris.herbst@asu.edu

\footnotetext{
${ }^{1}$ Elizabeth Kuttner provided excellent research assistance. I am grateful to participants at the 2016 Fall research meeting of the Association for Public Policy Analysis and Management for providing thoughtful comments and suggestions.
} 


\section{Introduction}

Families in the U.S. increasingly rely on non-parental child care as a crucial work support. Currently 13 million preschoolers - or $60 \%$ of children ages 0 to 5-regularly attend some form of child care, with the average child spending 32 hours per week in these settings (Mamedova et al., 2013; Laughlin, 2010). Catalyzed by the empirical evidence that child care quality is an important input to children's cognitive and social-emotional development, providers and policymakers are under mounting pressure to adopt quality-enhancing policies and practices that increase child wellbeing and school readiness (Auger et al., 2014; Hill et al., 2002; Keys et al., 2013; NICHD \& Duncan, 2003).

Over the past decade, Quality Rating and Improvement Systems (QRIS) have been promoted as a market-based tool to measure and increase quality across a range of early care and education (ECE) programs and, ultimately, to improve children's developmental outcomes. Currently 42 states administer a QRIS, and another six are in the process of piloting one. The recent flurry of activity around implementing QRIS stems from the 2011 federal Race to the Top-Early Learning Challenge (RTT-ELC), which requires states to have such a system already in effect or to be planning one.

Although states have considerable flexibility in designing their QRIS, there is broad agreement regarding its primary design features. Child care providers volunteer to be assessed in relation to a wide variety of quality indicators, including staff-child ratios, staff training and education, and the quality of the classroom learning environment. Providers then receive a summary rating - usually in the form of "stars" or a numerical value - along with financial resources and technical assistance to improve program quality. The ratings are disseminated to the public, with the intention that parents use this information to inform their child care decisions and, in turn, generate competition between providers.

Implicit in the design and goals of QRIS is a recognition that there are constraints on the ability of market actors to generate the socially optimal level of quality. Indeed, the child care market 
is often characterized by the presence of information asymmetries in which parents experience difficulties recognizing high-quality care and distinguishing it from programs of mediocre- or lowquality. ${ }^{2}$ For example, studies find a large divergence in the ratings of child care quality between parents and trained observers, with parents overstating the quality of their child's arrangement (Cryer \& Burchinal, 1997; Mocan, 2007). These challenges arise in part because child care is an experience good, whose key quality features are not observable prior to consumption. Such problems are likely exacerbated by the dearth of reliable information about providers, and by the way in which parents conduct the child care search. Recent surveys indicate that parents are more likely to inquire about program costs and hours-of-operation than about its quality attributes, and they generally consider just one or two providers before making a decision (Helbrun \& Howes, 1996; NSECE, 2014).

Child care providers also experience a number of constraints. Program directors may lack the expertise as well as access to the necessary technical assistance to make quality improvements. In addition, the labor-intensiveness of the child care industry means that quality enhancements typically stem from lowering child-staff ratios or hiring more experienced and highly-educated teachers, all of which are costly to undertake. Given the estimated price-sensitivity in the demand for child care, program directors may not have an incentive to invest in higher-quality services unless public resources are available to defray such costs (Blau \& Hagy, 1998).

By making information on program quality accessible to parents and increasing the availability of financial and technical assistance to providers, QRIS aims to alleviate these market constraints. Indeed, the logic model underlying QRIS implies that as parents learn about and use the child care ratings, preferences for quality attributes will increase, with parental demand likely shifting from low- to high-quality programs in an attempt to maximize child well-being. In particular, one might expect families to switch from parental and informal child care arrangements to formal

\footnotetext{
${ }^{2}$ It is noteworthy that most parents claim to value high-quality care. In a recent survey, fully 81 percent of parents stated that the presence of "learning activities" was "very important" in the selection of a child care arrangement (Mamedova et al., 2013).
} 
settings — such as center-based services — and be willing to pay more for this care. As a result, child care providers will have an incentive to participate in QRIS and offer higher-quality programming characterized in part by an increased supply of qualified teachers, higher staff compensation levels, and reduced turnover. These predictions imply that, in the long-run, market-wide quality will increase because undersubscribed low-quality programs will improve or exit the market.

The goal of this paper is to begin to empirically characterize the ways in which families and child care providers respond to the introduction of states' QRIS. Specifically, I assess the impact of QRIS on two sets of outcomes: (i) families' child care choices and maternal employment and (ii) the supply and compensation of child care labor. The analysis begins by drawing on repeated crosssections of families from the National Household Education Survey (NHES) and the Current Population Survey (CPS) to examine the type of child care families choose, hours of use, child care expenditures, and the labor supply of mothers with preschool-aged children. I then turn my attention to outcomes in the child care labor market. I rely on the CPS as well as panel data from the Quarterly Workforce Indicators series (QWI) to study the likelihood that women at different skill levels are employed in the child care industry, the supply of child care labor, earnings, and turnover. To identify the impact of QRIS, I estimate difference-in-differences (DD) models, taking advantage of the differential timing in the roll-out of QRIS across the states. Given that the presence and timing of QRIS enactment may be correlated with other state-level characteristics, the DD models include controls for unobserved state and temporal heterogeneity as well as state-specific time trends.

To my knowledge, this is the first attempt to examine family and provider responses to QRIS enactment. As described in Section II, most QRIS research to date focuses on either validating the quality ratings assigned to child care providers or examining the association between the ratings and child well-being. This study, in contrast, is concerned with an intermediate set of outcomes: that is, whether the implementation of QRIS alters the behavior of parents and providers in ways that reflect the fidelity of the ratings process and whose decisions in turn influence child development. 
Therefore, results from this analysis can inform whether QRIS is "working" in the sense that parents are using the ratings to inform their child care choices and providers are responding to the newfound competitive landscape. This paper also provides the first analysis of states' child care wage compensation programs, which provide teachers with one-time or periodic earnings supplements conditional on completing additional training or education. Currently operating in 14 states, these programs are viewed as powerful vehicles for achieving the workforce development targets embedded in the quality rating system. Thus I investigate whether QRIS, when paired with these wage initiatives, has different effects on the child care workforce relative to when QRIS operates without these complementary programs. A secondary contribution is that I rely on a number of published data sources as well as personal correspondence with program administrators in every state to carefully code the implementation date of each QRIS and wage compensation program. The available information is often conflicting and antiquated. Thus this study attempts to improve the quality of such information for others to use in future research.

The remainder of this paper proceeds as follows. Section II provides background information on QRIS, describing its main design features and summarizing the relevant literature. Section III introduces the data sources used in the analysis, while Section IV discusses the methodological approach. I present the paper's main results in Section V, and Section VI provides conclusions.

\section{Background}

\section{QRIS Description}

Implementation of a QRIS is now the predominant state-level approach to monitoring and improving quality across the spectrum of ECE settings. Indeed, as shown in Table 1 and Figure 1, the number of states operating a QRIS has grown dramatically since 1997, when the first state launched its system. Much of the impetus for enacting QRIS is driven by the growing pressure on policymakers to inject accountability into the provision of ECE services, and to increase uniformity in the definition of "high-quality" across various settings. 
As such, the goals of QRIS are to increase the supply of high-quality providers and, ultimately, to improve child development and school readiness. In principle these goals are achieved by defining standards for program quality, creating incentives and offering technical assistance to help providers meet the standards, and communicating transparently to consumers the level of quality attained by ECE programs (Zellman \& Perlman, 2008). More concretely, states' QRIS are generally comprised of four design features: (i) establishing a set of quality criteria, (ii) developing accountability measures that rate programs in relation to those criteria, (iii) giving programs the technical support and financial incentives to improve their quality rating, and (iv) engaging in consumer education activities that inform parents about the quality of care available in the market (Tout et al., 2010).

Although there is variation across states in the program components selected for quality assessment, the most common characteristics include child-to-staff ratios, group size, director and teacher training and education, and the learning environment. To evaluate the learning environment, states generally rely on a series of Environment Rating Scales (ERS), which provide program-level quality assessments of family child care homes $(\mathrm{FCCH})$ and classroom-level assessments of centerbased providers. ${ }^{3}$ These scales rate the physical features of the child care environment (e.g., health and safety characteristics) as well as the quantity and quality of interactions between teachers and children (e.g., level of stimulation, type of instruction, and degree of warmth/responsiveness). Once an ECE provider volunteers to enter the state's QRIS, it undergoes an evaluation in relation to the selected criteria, and a rating is produced-usually in the form of "stars" or another consumerfriendly symbol— to indicate its level of quality. States generally maintain four or five discrete levels of program quality, with each successive level denoted by an increasing number of stars (or steps). ${ }^{4}$

\footnotetext{
${ }^{3}$ Examples of these measures include the Family Child Care Environment Rating Scale-Revised (FCCERS-R) (Harms et al., 2007), the Infant/Toddler Environment Rating Scale-Revised (ITERS-R) (Harms et al., 2006), and the Early Childhood Environment Rating Scale-Revised (ECERS-R) (Harms et al., 2005).

${ }^{4}$ The levels are calculated using either a building blocks or points design: the former requires that all quality criteria must be met before a provider may proceed to a higher tier, while the latter assigns points to each quality criterion and stipulates that a certain
} 
As noted above, all states use a combination of technical assistance and financial incentives to encourage providers to enter the QRIS and improve quality once inside the system (Tout et al., 2010). Technical assistance usually consists of comprehensive provider feedback after a rating is issued, a detailed step-by-step plan to improve quality, and one or more "coaches" assigned to work with the provider. Financial incentives typically take the form of provider grants to invest in costly quality enhancements (e.g., educational material and professional training), staff salary supplements, and tiered reimbursements in which higher-ranked providers are paid more to serve children in the child care subsidy system. The final design feature-consumer education-involves a marketing campaign that publicizes the QRIS, gives parents access to program ratings (as well as information on how the ratings were determined), and allows providers to tout their program's quality.

An important question is whether child care providers and parents are aware of and participating in QRIS. Generally speaking, there are different reasons why low- and high-quality providers might participate in the rating process. For low-quality providers QRIS represents an opportunity to improve program quality and reputation as well as benefit from the available financial incentives and technical assistance. Indeed, given that low-quality providers are likely to be risk averse, they may be unwilling to participate in an assessment process that renders a low rating unless supports are available to lower the cost of expensive and difficult-to-change quality components (e.g., staff training and education). For high-quality providers the ratings system may be viewed as a vehicle for communicating the (already high) level of quality provided, thereby driving additional market demand to the provider.

Scattered evidence from state-specific studies generally reveals that ECE providers are willing to participate in QRIS. For example, an early study of multiple states finds provider

number of points must be obtained to achieve a higher rating. A building blocks scoring design increases the consistency of quality across programs, since all programs must meet the same benchmarks before moving up to a higher quality tier. On the other hand, resource-constrained providers may find it difficult to meet the benchmarks. A points-based design gives providers the flexibility to target the quality criteria they are most likely to be successful in meeting, but such a system also means that programs scoring high on one criterion but low on another may be rated equal to or greater than a program that achieved a moderate amount of broad-based quality improvement (Boller et al., 2015). 
participation rates of 97 percent in Oklahoma, 68 percent in Pennsylvania, and 10 percent in Colorado (Zellman \& Perlman, 2008). A recent study in Indiana finds that in the first three years of implementation, participation increased to 82 percent of child care centers and 52 percent of FCCHs (Elicker et al., 2011). Another recent study in Minnesota shows that 45 percent of centers and 10 percent of FCCHs were participating less than a year after statewide implementation (Minnesota Department of Human Services, 2015).

As for parents, there are several ways to assess awareness and engagement. Several states have conducted household surveys as part of a larger effort to evaluate their QRIS. These surveys generally ask whether parents are aware of the QRIS in their state as well as whether the program ratings are used in the child care decision. Results from these surveys reveal an uneven degree of parental awareness across the states, ranging from 17 percent in Kentucky and 37 percent in Indiana to 87 percent in Oklahoma (Elicker et al., 2011; Star et al., 2012; Zellman \& Perlman, 2008). Nevertheless, two-thirds of parents in Indiana and Oklahoma state that the number of "stars" given to a program would influence the choice of provider, and 50 percent of Indiana parents claim they would be willing to pay more for a higher-rated program. Another way to assess engagement is the extent to which parents visit the state QRIS website. Although these data are not available, a rough way to measure such activity is through the volume of state-specific Google searches for QRIS names (e.g., "Paths to Quality"). Figures 2a through 2j present this information for 10 states between October 1, 2013 and October 1, 2016. ${ }^{5}$ It is clear there is steady-and in some states increasinginterest in the QRIS names over this period. Colorado, in particular, provides a striking example: its current QRIS, Colorado Shines, was implemented in February 2015. This search term was rarely used prior to this date, after which it generated growing volume. Together, the evidence suggests that the public may be gradually learning about states' QRIS.

\footnotetext{
${ }^{5}$ It is important to note that this analysis was conducted for virtually every state. For most states, the QRIS name did not register at all, indicating very low levels of Google search activity over time. Thus the 10 states listed in Figures $2 \mathrm{a}$ through $2 \mathrm{j}$ are distinct, in that Google Trends rendered search volume results at all.
} 


\section{Relevant Literature}

Most research on QRIS focuses on whether program ratings are correlated with objective measures of quality, the extent to which program ratings improve over time, and the association between these ratings and child development (Tout, 2013). Regarding the first line of work, a review of 14 QRIS validation studies covering 11 states concludes that program ratings are positively correlated with ERS quality measures, but notes that such ERS's are usually among the components used to produce the rating (Karoly, 2014). When independent measures of quality are used instead, the association with program ratings is less clear. The most recent work in this area shows that although participation in QRIS increases quality relative to non-participating programs (Boller et al., 2015), the individual ratings may not translate into distinct levels of quality (Hestenes et al., 2015).

Regarding the second line of work-asking whether program quality or the rating itself improves over time - Karoly's (2014) review finds consistent evidence that programs participating in QRIS experience relatively steady progress. For example, evaluations of the Colorado, Florida, and Pennsylvania QRIS reveal increasing ERS scores in FCCH and center-based settings (Shen et al., 2009; Sirinides, 2010; Zellman et al., 2008). Furthermore, about 20 percent of Indiana's child care providers had advanced at least one quality level over a six-month period (Elicker et al., 2011), and approximately two-thirds of Minnesota's providers witnessed at least a one-star improvement during the 12-month window in between assessments (Tout et al., 2011).

The final stream of research-exploring the relationship between program ratings and child development - is currently the area in which credible evidence is most lacking. There are three longitudinal studies with adequate sample sizes that either carefully control for family and community characteristics or compare changes over time in children's test scores (Sabol \& Pianta, 2015; Tout et al., 2011; Zellman et al., 2008). Of these, just one study (of Virginia's QRIS) finds positive associations, specifically that children attending higher-rated pre-kindergarten programs experience larger gains in literacy skills (Sabol \& Pianta, 2015). A different approach to evaluating 
child outcomes is to simulate states' QRIS scoring algorithms using high-quality measures of ECE settings found in independently collected datasets, and then estimate the relationship between the simulated ratings and child development. One such study by Sabol et al. (2013) uncovers very few statistically significant associations between the program ratings and children's learning outcomes during the pre-kindergarten year.

\section{Data Sources}

As previously stated, the goal of this paper is to examine the impact of states' QRIS on two clusters of outcomes: (i) families' child care choices and maternal employment and (ii) the supply and compensation of child care labor. To do so, I draw on a variety of datasets and estimators, which are summarized in Appendix Table 1. Below is a detailed discussion of the data sources, the characteristics of the analytic samples, and the outcomes examined within each cluster.

\section{Child Care Choices and Maternal Employment}

To study families' child care choices, I rely on the National Household Education Survey (NHES), which is administered by the National Center for Education Statistics (NCES). Begun in 1991 as a family of surveys, the goal of the NHES is to provide descriptive information on the educational activities undertaken by the U.S. population. One of these surveys, covering Early Childhood Program Participation (ECPP), focuses on preschool-aged children's participation in (informal and formal) non-parental child care arrangements, the amount of time spent in those arrangements, and whether and how much families pay for child care. The questionnaire is completed by a parent or legal guardian who is most familiar with the focal child's caregiving arrangements.

Although the ECPP was administered in 1991, 1995, 2001, 2005, and 2012, I use pooled cross-sections from the 2005 and 2012 surveys given that the questionnaires in these years are highly comparable. This period is marked by dramatic growth in the adoption of QRIS. In 2005, nine states had introduced a QRIS, rising to 30 states by 2012. In the NHES sample, 17 percent of preschool- 
aged children resided in a state with a QRIS; by the 2012 survey that figure rose to 54 percent. The pooled analysis sample includes 14,270 children, of which 6,785 come from the 2005 survey and 7,485 come from the 2012 survey. The main results rely on the full sample, but I present separate estimations based on sub-sets of mothers with a high school degree or less $(\mathrm{N}=8,127)$ and mothers with more than a high school degree $(\mathrm{N}=5,732)$.

As shown in Table 2 (Panel A) and Appendix Table 1, I use the ECPP to analyze several outcomes related to families' child care choices and expenses. I begin by examining participation in the primary child care arrangement, defined as parent care, relative care (e.g., grandparents and other non-parent family members), non-relative care in the child's home (e.g., babysitters and au pairs), non-relative care in another person's home (e.g., FCCH's), or center-based care (e.g., child care center, preschool, pre-k, and Head Start). Although the ECPP inquires about participation in multiple arrangements, it measures the "primary" arrangement as the one in which the focal child spends the most hours each week. In addition, I examine the total number of hours per week of non-parental child care use, whether the family makes a payment for child care, total weekly expenditures, and expenditures per hour of child care use. To calculate hourly expenditures, I sum weekly expenses across all arrangements, and divide this amount by the number of weekly hours spent in those arrangements. Both expenditure variables are adjusted for inflation.

Panel A of Table 2 shows that about 37 percent children ages 0 to 5 are primarily in parent care, while the predominant modes of non-parental care are center-based (33 percent) and relative (18 percent) arrangements. Far fewer children are provided care in non-relative and family-based settings ( 3 percent and 9 percent, respectively). On average preschool-age children participate in nonparental care for approximately 18 hours each week, and 43 percent of families pay for these services. The typical family pays a little over $\$ 56$ per week for child care, amounting to $\$ 2.60$ per hour of use. Table 2 also reveals that children of high-skilled mothers are less likely to be in parent care and more likely to participate in center-based settings than their low-skilled counterparts. In 
addition, high-skilled families are more likely to pay for child care, and their expenses per week and per hour are substantially higher.

To examine mothers' labor market outcomes, I rely on the March Demographic Supplement to the Current Population Survey (CPS) (King et al., 2010). The CPS is a nationally representative survey of 60,000 to 100,000 households, providing detailed data on labor market behavior, income, and demographic characteristics for nearly 200,000 individuals ages 15 and over. March CPS surveys for years 1992 to 2015 are used, yielding information on employment and earnings for the years 1991 to 2014 . I include in the sample civilian women ages 18 to 64 whose youngest child is ages 0 to 5 . The resulting sample includes 259,005 mothers. Once again, I estimate the overall effect of QRIS as well as separate effects for mothers with a high school degree or less $(\mathrm{N}=108,915)$ and mothers with more than a high school degree $(\mathrm{N}=150,090)$.

The labor market outcomes include a measure of any employment in the previous calendar year, the number of weeks worked last year, the weekly number of hours worked, and the hourly wage (adjusted for inflation). Hourly wages are defined as total annual earnings (pre-tax wages, salary, and self-employment) divided by the number of hours worked in the previous year. Annual hours is created by multiplying the variables for weekly hours of work and annual weeks of work. As shown in Panel B of Table 2, approximately 67 percent of mothers with preschool-age children did any work in the previous year. On average they were employed for 29 weeks throughout the year and for 23 hours during a typical week. The full sample hourly wage rate is about $\$ 15$. High-skilled mothers are more likely to be employed, they accrue more work throughout the year and week, and they earn substantially more per hour than their low-skilled counterparts.

\section{Supply and Compensation of Child Care Labor}

I begin this section by studying the impact of QRIS on the decision to become a child care worker. Given that the child care industry very labor intensive, results from this analysis should inform the way in which QRIS influences the supply of child care (Blau, 2003). I then examine the 
hourly wages of child care workers in various sectors. These analyses are based on individual-level data from the March Demographic Supplement to the CPS (King et al., 2010). I use March CPS surveys for years 1992 to 2015, yielding information on employment and wages for the years 1991 to 2014. Included in the sample are civilian women ages 18 to 64. Men are not included because over 95 percent of child care workers are female (author's calculation of the March CPS). The analysis sample includes $1,365,519$ individuals.

I analyze women's decision to choose employment in one of three child care sectors: home-, center-, and school-based sector. These individuals are identified through the industry and occupation codes attached to the primary job held in the previous year. ${ }^{6}$ Center-based workers include non-selfemployed individuals who work in either the "child day care services" industry in any occupation (e.g., "child care workers" or "prekindergarten and kindergarten teachers") except home-based child care occupations (e.g., "family child care providers" or "private household child care workers") or in a child care occupation (i.e., "child care workers") that does not reside in a home- or school-based industry (i.e., "private households," "individual and family services," "family child care homes," or "elementary and secondary schools"). Home-based workers include self-employed individuals working in the "child day care services" industry, those employed in the "family child care homes" industry, those who have early care and education occupations (i.e., "child care workers," "private household child care workers," "prekindergarten and kindergarten teachers," and "early childhood teacher's assistants") within the "private households" or "individual and family services" industries, or those who are self-employed with child care occupations residing in any industry except “elementary and secondary schools." Finally, school-based child care workers are not self-employed and work in the "elementary and secondary schools" industry with early care and education occupations (i.e., "child care workers," "pre-kindergarten or kindergarten teachers," or "early

\footnotetext{
${ }^{6}$ To construct these categories, I draw on previous work by Blau (1992), Herzenberg et al. (2005), Bassok et al. (2013), and Herbst (2015).
} 
childhood teacher's assistants"). ${ }^{7}$ Based on these definitions, the sample includes 12,117 home-based workers (1 percent of the sample), 18,214 center-based workers (1.3 percent), 17,100 school-based workers (1.3 percent), and 959,665 non-child care workers (70 percent). The remaining women in the sample are coded as non-workers ( $\mathrm{N}=358,423$ or 26 percent).

Hourly wages are defined in the same manner as the maternal employment analysis. As shown in Panel A of Table 3, child care workers (as a group) earn $\$ 13$ per hour, while their non-child care counterparts earn approximately $\$ 22$ per hour. ${ }^{8}$ Comparing wages by education level, it is clear that a skill premium exists within the child care industry: those with at least some college education earn 38 percent more than those with no more than a high school degree ( $\$ 15$ versus $\$ 11$ per hour). However, the skill premium is substantially larger for women working in non-child care sectors: highly-educated women earn 61 percent more per hour ( $\$ 25$ versus $\$ 16$ per hour).

To further investigate the supply and compensation of child care labor, I utilize the Quarterly Workforce Indicators (QWI) series, which provides local labor market measures disaggregated by industry code, employee demographic characteristics, and firm characteristics. ${ }^{9}$ The underlying data source for the QWI is the Longitudinal Employer-Household Dynamics (LEHD) microdata, which links employers with its employees across virtually all private-sector jobs in the U.S. These data connect individual-level earnings data from Unemployment Insurance records, firm-level characteristics from the Quarterly Census of Employment and Wages (QCEW), and demographic information from the Decennial Census, Social Security Administration records, and individual tax returns. Such linkages allow for the analysis of employment and earnings disaggregated by industry and geography as well as by employees' educational attainment, race and ethnicity, and other

\footnotetext{
7 Some may quibble with the label "school-based child care worker" to describe a group of individuals that includes prekindergarten and kindergarten teachers. Note that this label is for the purpose of ease of discussion only. Given that prekindergarten and kindergarten teachers are commingled in the CPS's occupation coding, to include the former in the definition of child care worker (which, I argue, is appropriate) I must include the latter as well.

${ }^{8}$ Women employed in home-based settings are the lowest-paid child care workers ( $\$ 9$ per hour); those in center-based settings earn slghtly more (\$13); and school-based child care workers are the most highly-paid $(\$ 16)$.

${ }^{9}$ An introduction to the data and a description of the labor market indicators can be found here: http://lehd.ces.census.gov/doc/QWI_101.pdf.
} 
characteristics. All 50 states and the District of Columbia participate in this data-sharing arrangement with the Bureau of Labor Statistics (BLS), although states began participating at different times.

For the purposes of this study, I examine six labor market indicators for the "Child Day Care Services" industry (NAICS 4-digit code 6244): total employment, new hires, job separations, turnover, real monthly earnings, and real new hires' monthly earnings. ${ }^{10}$ This industry code includes UI-covered individuals working in the public (e.g., Head Start) and private (e.g., for-profit centers and non-profit churches) sectors, and potentially those operating or employed by FCCHs. The definition likely excludes the employment and earnings of informal caregivers, such as neighbors, relatives, and nannies, as these individuals are not generally UI-covered. It should also be noted that the definition covers workers in a variety of occupations, including those in instructional roles, such as child care teachers or teacher's assistants. However, it also covers the CEOs and managers of national chains, administrative support staff, food preparation and facilities maintenance workers, bus drivers, and many other non-instructional occupational categories.

I express the first three outcomes in per capita terms, dividing by the state population ages 0 to 4, and I take the natural $\log$ of all outcomes. The analysis dataset is constructed by first downloading these indicators for women in all age-groups, racial and ethnic categories, states, and calendar quarters over the period 1993 to 2015, and then disaggregating the data by employees' level of education (less than high school, high school degree/GED, some college/associate's degree, bachelor's degree and above, and educational attainment unavailable). Young employees—defined by the QWI as those ages 24 and younger-are not assigned to an educational attainment category.

\footnotetext{
${ }^{10}$ Total employment is defined as beginning-of-quarter employment counts, or the total number of positions held on the first day of the reference quarter. New hires is defined as the number of workers employed at a given firm in the reference quarter who were not employed there in any of the previous four quarters. Separations is defined as the total number of workers whose job with a given firm ended in the specified reference quarter. The turnover rate is calculated by summing the number of hires and separations in a given quarter and dividing by the average full-quarter employment. Monthly earnings are defined as earnings for those who were working with the same firm throughout the entire quarter. Finally, the measure of new hires' earnings is defined as the average monthly earnings for workers who began employment with a given firm in the previous quarter.
} 
These workers are combined into a stand-alone category that may be analyzed separately. The resulting dataset is an unbalanced panel of 3,683 state-by-quarter combinations.

Panel B of Table 3 presents summary statistics for the QWI outcomes for the full sample and the sub-sets of low- and high-skilled employees. The average quarterly turnover rate in the child care industry is approximately 14 percent, with high-skilled workers turning-over at a lower rate than their low-skilled counterparts. Not surprisingly, the average monthly earnings of newly hired workers $(\$ 1,036)$ are lower than the average for the full child care industry $(\$ 1,651)$. Consistent with the CPS, the QWI reveals a sizeable skill premium: child care workers with less than a high school degree earn about $\$ 1,526$ per month, while those with at least a college degree earn $\$ 2,183$ (or 43 percent more).

\section{Measurement of QRIS}

The primary right-hand-side variable is a measure of whether a given state has a QRIS, and if so, when it was implemented. Table 1 provides information on the enactment dates (month and year) for states' pilot QRIS, if applicable, and full QRIS. To collect this information, a number of on-line resources and published documents were consulted, including the QRIS Compendium, QRIS National Learning Network, QRIS Resource Guide, National Child Care Information Center (2006), Tout et al. (2010), and Zellman and Perlman (2008). However, given that these sources often provided conflicting or outdated information, the decision was made to contact one or more QRIS (or early childhood program) administrators in every state to ascertain (i) whether it ever enacted a pilot or full QRIS, (ii) whether the systems are statewide or regional, and (iii) the month and year in which the pilot and full systems were launched. Information was obtained on the month and year of pilot and full QRIS implementation for all states except Rhode Island, where just the start year of the pilot was recorded. ${ }^{11}$

\footnotetext{
${ }^{11}$ Several other pieces of information were collected from state administrators. All of this information will be made available to researchers upon request. A quick note about Colorado's QRIS enactment date, which is listed as February 2015: prior to Colorado Shines (the state's current QRIS), it operated a QRS called Qualistar, which was introduced in 2000. Qualistar did not contain a funded, integrated system of quality improvement and technical assistance aimed at increasing child care quality. Thus
} 


\section{Empirical Strategy}

The goal of this paper is to isolate the impact of states' QRIS on families' child care choices as well as the supply and compensation of child care labor. The key empirical concern is that there are likely to be a number of characteristics correlated with whether a given state has implemented a QRIS. For example, it is possible that relatively wealthy states, those with a large and well-trained child care workforce, or those with strong political support for ECE generally may be more likely to implement a QRIS. It is also possible that national events or changes in federal policy may be correlated with QRIS enactment. One clear example is President Obama's RTT-ELS, which was authorized in 2011 under the American Recovery and Reinvestment Act (ARRA). By distributing grants to states, the RTT-ELS seeks to incentive the creation of high-quality early learning systems in part by urging states to strengthen or develop a QRIS. ${ }^{12}$ If these state and national characteristics are not accounted for, it is likely that the observed differences in outcomes between states with and without a QRIS may be inappropriately attributed to the QRIS.

To address this concern, I utilize a difference-in-differences (DD) approach, exploiting temporal variation in the implementation of QRIS across the states. As shown in Figure 1, the number of states with a QRIS grew to 38 between 1997-the year of the first QRIS - and 2015. Although the analysis relies on different data sources with varying structures and observation periods, the basic DD model can be formalized as follows:

$$
O_{\mathrm{ist}}=\beta_{1} Q R I S_{\mathrm{st}}+\mathbf{X}^{\prime} \gamma+\mathbf{S}^{\prime} \gamma+\delta_{\text {state }_{\mathrm{s}}}+\delta_{\text {year }}+\left(\text { state }_{\mathrm{s}} \times \text { trend }_{\mathrm{t}}\right)+\varepsilon_{\mathrm{ist}},
$$

where $O$ represents an outcome related to families' child care choices, mothers' employment, or the supply and compensation of child care labor for family/individual $i$, residing in state $s$ at time $t$. Recall that analyses based on the NHES and CPS use individual-level data, while those based on the QWI use state-level data. The relevant time period in the NHES and CPS is the year, and it is the calendar quarter in the QWI. The variable $Q R I S$, which is the variable of interest, is a binary

the decision was made to code the start date of Colorado's system as February 2015, when the QRIS was enacted. Nevertheless, I estimate all models in this paper, recoding the state's implementation date as 2000 , and similar results are obtained.

${ }^{12}$ Between 2012 and 2014, 20 states were awarded four-year grants through the RTT-ELS. 
indicator that equals unity if a state has a QRIS implemented in a given period, and zero otherwise. The model includes a set of observable individual-level controls (denoted by $\mathbf{X}^{\prime}$ and included in the NHES and CPS analyses) and time-varying state controls (denoted by $\mathbf{S}^{\prime}$ and included in all analyses) that may be correlated with the presence of a QRIS. ${ }^{13}$ A major advantage of the DD model is that it allows for controls for unobserved state-specific heterogeneity (denoted by state $_{\mathrm{s}}$ ) as well as for period-specific effects (denoted by year ${ }_{\mathrm{t}}$ ).

As with all DD models, the primary identification assumption in [1] is that of common outcome trends between states with and without a QRIS prior to the enactment of QRIS. To examine the validity of this assumption, I present in Figure 3 the six child care workforce outcomes from the QWI for states with and without a QRIS in the 20 quarters prior to and after enactment. Given that states began operating QRIS in different years, I center each graph at the quarter in which it became effective (i.e., at time zero), as indicated by the vertical line. Thus the data presented to the left of the line show the outcome trends for states that ultimately enacted and never enacted a QRIS. The figures show a close correspondence in these pre-reform trends, indicating that the DD coefficient on QRIS should not be confounded by preexisting differences between states with and without a QRIS. Nevertheless, I include in the models using the QWI a set of state-specific linear time trends (denoted by state $_{\mathrm{s}} \times$ trend $_{\mathrm{t}}$ ) to control for any differential trends in the outcomes across the states.

The coefficient of interest, $\beta_{1}$, provides an estimate of the average difference in a given outcome for those in states with and without a QRIS. Given that the variable QRIS takes a value of one for all states with a QRIS (and zero for all states without a QRIS), an assumption imposed by the modelling strategy is that of homogenous policy treatments and treatment effects across time,

\footnotetext{
13 The individual-level controls in the NHES include the focal child's gender, age, race/ethnicity, mother's age and age-squared, mother's marital status, mother's educational attainment, total household size, number of individuals in the household under age six, and total household income. The individual-level controls in the CPS analysis of maternal employment include age, agesquared, race/ethnicity, marital status, educational attainment, presence of a work disability, family size, age of the youngest child, and the total number of children in the household. The individual-level controls in the CPS analysis of the child care labor market include age, age-squared, race/ethnicity, marital status, educational attainment, presence of a work disability, family size, age of the youngest child, and the total number of children in the household under age 5. The state-level controls in all analyses include the unemployment rate, per capita income, and population density.
} 
geographical boundaries, and sub-groups of families and child care providers. This is clearly a strong assumption. For example, states and localities may vary substantially in the design and administration of their QRIS, including the types of providers eligible for a rating, whether participation is compulsory, the components of quality chosen for assessment, and the provider supports (including financial incentives) available to improve program quality. These considerations suggest that it is appropriate to interpret $\beta_{1}$ as averages of heterogeneous effects of QRIS across families and providers exposed to different types and varying amounts of the QRIS policy treatment. To probe for heterogeneous effects of QRIS, the empirical analyses undertake a series of sub-group estimations by maternal and provider skill level. Such analyses should inform whether there are differential demand- and supply-side responses to QRIS enactment.

As outlined in Appendix Table 1, the model for families' child care choices (NHES) and women's child care sectoral choices (CPS) is estimated using a multinomial logit model (MNLM). The alternatives in the former model are relative care, non-relative care, family-based arrangements, center-based arrangements, and parent care (base category). The alternatives in the latter model are home-, center-, and school-based based child care workers; non-child care workers (i.e., all other sectors); and non-workers (base category). The model for the hours of child care use and weeks and hours of maternal employment is estimated with a tobit model. The other outcomes are estimated using ordinary least squares (OLS) regression. All models use the full analysis samples, including families that do not use non-parental child care or do not pay for care as well as women who do not work (and thus have zero wages). Non-users of child care and non-workers therefore take a value of zero for hours-of-use and weeks- and hours-of-work. In the models for log child care expenditures and log hourly wages, the outcomes are also set equal to zero for non-users of child care and nonworkers. As a result, the coefficient on QRIS represents the overall effect of QRIS, averaging the 
effect on the probability of using any child care or doing any paid work with the effect on the amount paid or earned. ${ }^{14}$

\section{Estimation Results}

\section{Child Care Choices and Maternal Employment}

Tables 4 and 5 provide estimates of the impact of QRIS on families' child care choices and mothers' labor supply, respectively. Panel A of both tables displays the full-sample estimates, while Panels B and C examine the differential effect of QRIS across sub-sets of low- and high-skilled mothers, respectively. Low-skilled mothers are defined as those with a high school degree or less, while high-skilled mothers are those with more than a high school degree. For ease of exposition, I refer to these as "disadvantaged" and "advantaged" families throughout the discussion. All models include the full set of controls, and the standard errors are adjusted for arbitrary forms of heteroskedasticity as well as state-year clustering.

The first four columns in Table 4 present odds ratios from the MNLM of families' child care choices, using parent care as the base category. Panel A indicates that the implementation of QRIS induces a shift from parental to non-parental child care settings, particularly relative and non-relative arrangements. However, Panels B and C reveal substantial heterogeneity in families' response to QRIS. Disadvantaged families (i.e., those with low-skilled mothers) are more likely to utilize informal child care arrangements, while their advantaged counterparts (i.e., those with high-skilled mothers) rely increasingly on formal arrangements. For example, among disadvantaged families the enactment of QRIS increases the odds of using relative care approximately 30 percent, compared to a 10 percent increase in the likelihood of using family- and center-based arrangements. On the other hand, advantaged families witness relatively large shifts into the use of formal providers: such families are 42 percent more likely to rely on family-based care and 20 percent more likely to use

\footnotetext{
${ }^{14}$ In his analysis of the impact of child care regulations on the child care and maternal labor markets, Blau (2003) also adopts the practice of including non-users of child care and non-workers in the analysis sample. Conditioning on these behaviors would lead to a self-selected sample. In addition, there are no credible instruments available to identify the selection equations.
} 
center-based arrangements. Given the growing reliance on non-parental care, it is not surprising that QRIS implementation also increases the number of hours per week that children participate in these settings. As shown in the fifth column, children spend an additional two hours in non-parental care irrespective of whether they reside in disadvantaged or advantaged families.

The remaining columns in Table 4 pertain to families' child care expenses. Although the fullsample results indicate that QRIS does not appear to alter spending patterns, there is once again substantial differences across disadvantaged and advantaged families. Among the former set of families, QRIS reduces the likelihood of paying for non-parental care (by four percentage points) and reduces the amount paid per hour of utilization (by nine percent). Conversely, the latter set of families experiences increases in both the likelihood of paying (by five percentage points) and the amount paid (by 10 percent).

The divergence in child care expenses may be a function of QRIS's differential effect on the types of arrangements selected by disadvantaged and advantaged families, as discussed above. Indeed, NHES data show that, in general, those using informal arrangements, such as relative care, are less likely to pay out-of-pocket costs and, conditional on making a payment, spend less per hour than those using formal modes of child care, such center-based services. ${ }^{15}$ In other words, these patterns imply that the estimated increase in child care expenses faced by advantaged families reflect the growing use of child care arrangements that are more likely to charge, and charge more per hour, than other forms of care. The increase in expenses does not necessarily indicate that a particular type of child care arrangement became more expensive following the implementation of QRIS. In results not reported in the table, I examine this issue by estimating the hourly expense equation separately for each arrangement, conditional on using and paying for it. Overall, hourly expenditures on centerbased care fell 10 percent following QRIS enactment. This decrease is driven exclusively by the

\footnotetext{
15 Overall, 22 percent of families using relative care pay out-of-pocket costs, compared to 74 percent among those using centerbased care. Among those making a payment, \$4.97 is spent per hour on relative care, and \$7.39 is spent per hour on center-based care.
} 
reduction among disadvantaged families ( 24 percent); center-based expenses did not change among their advantaged counterparts ( 0.7 percent increase). The continued divergence in expenses after "controlling" for the type of arrangement used is consistent with two explanations: disadvantaged families may be more likely to receive a subsidy through the state's tiered QRIS, or they may switch to lower-cost centers operating outside of the state's rating system to avoid being charged more by those participating in it.

Given that the implementation of QRIS induced families to shift from parental to nonparental child care, it is reasonable to ask whether there has been a corresponding increase in maternal employment. To answer this question I turn to the CPS, which includes detailed labor market information on a large sample of families over a substantial time period. Table 5 presents DD estimates of the impact of QRIS on mothers' work decisions, weeks and hours of work, and hourly wages. Consistent with the increased use of non-parental care, mothers of young children are more likely to be employed, work more intensively, and experience an increase in wages after QRIS is implemented (Panel A). However, also consistent with the child care results is that these employment-effects are concentrated exclusively on advantaged mothers (Panel C). In fact, the DD estimates imply that employment and wages may have declined somewhat among disadvantaged mothers (Panel B).

\section{Supply and Compensation of Child Care Labor}

Tables 6 and 7 show estimates of the impact of QRIS on the supply and compensation of child care workers. Table 6 examines women's decision to work in various sectors of the child care industry as well as hourly wages, while Table 7 examines supply, earnings, and turnover within the NAICS "child day care services" industry. As with child care choice analysis, I examine the differential effect of QRIS across sub-sets of low- and high-skilled women. Panel A of Table 6 displays the full-sample estimates, while Panels B and C examine women with a high school degree or less (the low-skilled sub-sample) and those with more than a high school degree (the high-skilled 
sub-sample), respectively. Table 7 examines employment outcomes across a finer set of education categories, ranging from "less than a high school degree" to a "bachelor's degree or more." All models include the full set of controls, and the standard errors are adjusted for arbitrary forms of heteroskedasticity as well as state-year clustering.

The first three columns in Table 6 present odds ratios from the MNLM of women's sectoral choices, using non-working women as the base category. ${ }^{16}$ Panel A reveals that working-age women increasingly select into child care employment - particularly into center-based settings — after the implementation of QRIS. Specifically, the estimates indicate that QRIS increases the likelihood of choosing center-based employment by 10 percent. As shown in Panels B and C, the increasing attractiveness of center-based employment is driven by high-skilled women, whose likelihood of working in such settings grew by 15 percent. Employment in the other child care sectors does not appear to be influenced by QRIS enactment. The last column in Table 6 presents estimates from the hourly wage equation, revealing very little change in the earnings of child care workers as a group. In results not reported in the table, I estimate separate wage equations by child care sector and skilllevel. The QRIS coefficients are generally small in magnitude and statistically insignificant, with one exception: high-skilled center-based workers experience nearly a four percent reduction in wages.

The analyses presented in Table 7 provide a supplementary investigation into the supply and compensation of child care labor, using panel data from the QWI. For each outcome, Panel A displays the overall effect of QRIS; Panels B through E present separate estimates by the level of employee education; and Panel F is constrained to employees ages 24 and younger. The first column examines total child care industry employment — a proxy for the supply of child care — and finds very little change in employment following QRIS enactment, both overall and within each level of employee education. The second column analyzes the supply of new hires, defined as those who

\footnotetext{
${ }^{16}$ In addition to the three child care sectors (center-, home-, and school-based employment) and non-working women, the model includes a fifth category: working women in all non-child care sectors. To conserve space, estimates from this category are not presented in Table 6.
} 
began their employment with a child care provider in the current calendar quarter. The evidence suggests that QRIS increases the supply of new child care workers across all levels of education. For example, the number of new workers with less than a high school degree increased approximately five percent (Panel B), while the number of new workers with at least a bachelor's degree grew over three percent (Panel E). Also noteworthy is that the number of newly-employed young child care employees increased four percent following QRIS implementation (Panel F).

The next two columns examine the number of quarterly job separations and the turnover rate. The QRIS coefficients in the model for job separations are consistently positive, represent non-trivial magnitudes (a two to three percent increase per quarter), and are statistically significant. It is also noteworthy that the coefficients for new hires and job separations are approximately equal in magnitude, both overall and within each level of education. Such a pattern provides one explanation for why total child care employment does not change: the increase in new child care workers is matched by the roughly equal-sized departure of existing workers. Regarding employee turnover, it is well-known that the child care industry is characterized by high turnover rates, although some recent evidence suggests that it may have declined over the last two decades. Indeed, Bassok et al. (2013) show that annual turnover in the ECE industry decreased substantially between 1990 and 2010, from 33 percent to 24 percent. However, the estimates in Table 7 imply that QRIS enactment is associated with increases in turnover among lower-skilled and younger child care workers.

The last two columns in Table 7 examine the relationship between QRIS and two measures of child care compensation: average monthly earnings across all employees and average monthly new hires' earnings. It appears that monthly earnings increased following QRIS enactment, particularly among lower-skilled child care workers. Panels B through D show that employees with some college education or less witnessed an increase in earnings between 0.7 and 0.8 percent, while those with at least a bachelor's degree experienced only a 0.2 percent increase (Panel E). In addition, when operating under a QRIS, newly-hired child care workers receive a higher wage, as shown in the 
final column, although none of the category-specific coefficients are statistically significant, with one exception: young, newly-hired workers receive an earnings boost of 1.3 percent (Panel F).

\section{Differential Timing in the Effects of QRIS Enactment}

To this point, the DD analysis estimates the average effect of QRIS over the entire postenactment period. Given the complexities of introducing a quality rating system as well as enticing large numbers of parents and providers to engage with it, a reasonable assumption is that the DD estimates mask substantial heterogeneity across the early and later periods of enactment. In other words, there may be differential effects of QRIS immediately after enactment—when the system may not be fully functional—versus several years after enactment—when parent and provider engagement is likely to be higher. This assumption is particularly plausible in light of the fact that 13 of the states introducing a QRIS did not operate a pilot program beforehand (see Table 1).

To examine the dynamic effect of QRIS, I estimate a version of the DD model that includes several post-enactment dummy variables: one year after enactment, two to three years after, four to five years after, six to seven years after, and eight or more years after enactment. I estimate this model on the six QWI child care supply and compensation outcomes, and I the plot the periodspecific DD coefficients (along with the 90 percent confidence intervals) in Figure 4. It appears that the effect of QRIS is comparatively small and stable in the first three years of implementation. However, the supply of child care starts increasing in years four and five, followed by rising compensation in years six and seven. Although job separations and turnover do not change markedly in the first few years, there are increases in both starting in years six and seven. Together, this evidence suggests that QRIS may not have an immediate effect on the child care labor market; rather the impacts, if any, materialize after several years, when the system is likely to be fully operational.

\section{The Role of Wage Compensation Programs}

Over the past decade, states have begun operating wage compensation programs aimed at narrowing the pay gap between child care workers and other early education teachers (e.g., Head 
Start and pre-kindergarten teachers) as well as to attract and retain a highly-skilled workforce. The most common approach to increasing child care compensation is through one-time or (regular) annual wage stipends provided to individual employees. Generally speaking, an individual must apply for such funds and is required to meet a number of eligibility criteria, such as obtaining certain education or professional credentials and meeting job tenure targets. For example, eligibility for Wisconsin's REWARD stipend is conditional on working at least 20 hours per week at a certified family- or center-based program for three continuous years; completing three credits of ECE coursework at a community college or four-year university; and earning no more than $\$ 16.50$ per hour. Once these criteria are met, child care teachers may receive annual, incremental stipends ranging from $\$ 100$ to $\$ 900$. Another approach to supplementing wages is through refundable tax credits. Louisiana's School Readiness Tax Credit is one such example, which conditions eligibility on obtaining six months of employment in a child care center that participates in the state's QRIS. Tax credits ranging from $\$ 1,573$ to $\$ 3,146$ are provided to directors and teachers who achieve increasing levels of education as specified by the career development lattice system.

As previously mentioned, most states incorporate teacher education and professional development into the calculation of the quality rating. Thus wage compensation programs may be viewed as complementary to the goals of QRIS, in that they provide strong incentives for child care staff to undertake the activities that lead to both increased wages and a higher quality rating for the provider. In fact, in several states-including Arizona, Louisiana, and Pennsylvania - the wage compensation program is administered under the auspices of the QRIS and therefore requires staff to be working for a provider that participates in its QRIS. Although other states implement the wage program outside of the QRIS, the presence of such programs sends a strong signal that increased child care compensation is integral to quality improvement.

It is therefore important to examine whether QRIS, when paired with policy initiatives that provide wage supplements, has different effects on the child care workforce relative to when QRIS 
operates without these seemingly complementary programs. To do so, I estimate a DD model that takes the following form:

$$
\begin{aligned}
& O_{\text {ist }}=\beta_{1} Q R I S \_O N L Y_{\mathrm{st}}+\beta_{2} C O M P \_O N L Y_{\mathrm{st}}+\beta_{3} B O T H_{\mathrm{st}}+\mathbf{X}^{\prime} \gamma+\mathbf{S}^{\prime} \gamma+\delta \text { state }_{\mathrm{s}}+ \\
& \text { Syear }_{\mathrm{t}}+\left(\text { State }_{\mathrm{s}} \times \text { trend }_{\mathrm{t}}\right)+\varepsilon_{\text {ist }} \text {, }
\end{aligned}
$$

where QRIS_ONLY is a binary indicator that equals unity if a state administers a QRIS but does not operate a wage compensation program; COMP_ONLY is a binary indicator that equals unity if a state administers a wage program but does not have a QRIS; and BOTH is a binary indicator that equals unity if the state administers a QRIS as well as a wage program, irrespective of whether it is run under the auspices of the QRIS. The model uses states without a QRIS and wage compensation program as the omitted category. As shown in Table 1, 14 states implemented a wage program during the study period, with the first state (North Carolina) doing so since 1999 and the last state (Iowa) doing so since 2013. Thus, as with the variable QRIS in the previous DD analyses, there is substantial temporal variation in the introduction of these wage programs.

Table 8 presents results from [2] using the QWI workforce outcomes. For brevity, I present only the estimates based on the outcomes for all child care industry employees (i.e., equivalent to Panel A in Table 7). ${ }^{17}$ Generally speaking, the results imply substantial heterogeneity in the supply and compensation of child care workers depending on the mix of programs in place. Estimates in the first row show that compared to states with neither program, those with only a QRIS have a greater supply of new child care workers, but also more job separations and turnover and compensation levels that are no different. The second row shows that although the supply of new child care is lower in states with only a wage compensation program, job separations and turnover are also lower and earnings are higher. Finally, as displayed in the third row, states with both programs in place tend to have a greater supply of child care, lower turnover rates, and higher compensation levels. The last

\footnotetext{
${ }^{17}$ Approximately 63 percent of state-quarter observations in the QWI did not have a QRIS or a wage compensation program; 19 percent had just a QRIS in effect; eight percent had just a wage compensation program; and 10 percent had both.
} 
two rows test whether the coefficients on $Q R I S \_O N L Y$ are statistically different from those on COMP_ONLY and BOTH. In most cases the null hypothesis of no difference between the coefficients is strongly rejected, suggesting that states with a wage compensation program in place-either in isolation or paired with a QRIS — lead to different child care workforce outcomes than in states with just a QRIS in place. $^{18}$

\section{Falsification Test}

In the final set of analyses, I implement a placebo reform that "turns on" the QRIS in the years prior to its actual enactment. Specifically, I estimate a DD model that includes separate binary indicators for the five years prior to the state's QRIS implementation date, along with the primary QRIS variable discussed in [1]. If the common trends assumption is satisfied-that is, if there are similar pre-reform outcome trends across states with and without a QRIS - then the coefficients on the five QRIS lags should be statistically insignificant. For brevity, I perform the falsification test on the QWI data, using only the outcomes for all child care industry employees.

Results from this exercise are presented in Table 9. Generally speaking, the estimates are consistent with the conclusion that QRIS enactment has a causal effect on the outcomes of interest. Coefficients on the lagged QRIS variables are typically small in magnitude and not statistically distinguishable from zero. However, once a QRIS is enacted, there is a markedly larger effect on new hires, separations and turnover, and monthly earnings, as indicated by the coefficient on QRIS. In contrast, the evidence that QRIS has a casual effect on total child care employment is much weaker (first column). Coefficients on four of the five lags are statistically significant and of a sizeable

\footnotetext{
${ }^{18}$ I undertake a similar set of analyses using the child care workforce outcomes in the CPS. Although the pattern of results is similar to that in the QWI, some discussion is warranted. Regarding the child care sectoral choice model, low-skilled women are no more likely to choose center-based employment if a wage compensation program is in place. However, they are more likely to choose family-based employment if such a program is place. Among high-skilled women, having both a QRIS and a wage program increases the likelihood of choosing center-based employment, but does not alter decisions regarding family-based employment. Regarding hourly wages, low-skilled center-based workers experience an approximately equal-sized increase in wages regardless of whether a QRIS or wage program (or both) is in place. Low-skilled family-based workers in states with both programs witness a large and statistically significant increase in wages (approximately 10 percent), while their counterparts in QRIS-only and wage-compensation-only states experience no change in earnings. High-skilled center- and family-based workers, on the other hand, do not experience a change in earnings no matter the mix of programs in place.
} 
magnitude, indicating that there may have been differential changes in employment prior to the introduction of states' QRIS.

\section{Discussion}

As QRIS continues to gain traction as a key policy mechanism for measuring, monitoring, and increasing child care quality, there is clearly a growing need for research to inform whether these goals are being met. To date most scholarly work on QRIS focuses on determining whether the assigned provider ratings are in fact correlated with objective measures of quality, while a significantly smaller group of studies examines the relationship between the ratings and child outcomes. This paper, in contrast, is concerned with an intermediate set of questions: to what extent has the roll-out of QRIS influenced families' child care choices as well as the supply and compensation of child care labor? Such questions are important because a key justification for QRIS is that the presence of information asymmetries is responsible for suppressing child care quality: parents lack adequate information to distinguish between low- and high-quality care, and providers have little incentive to make costly quality investments. Indeed, by making program quality transparent to the public and offering financial incentives and technical assistance to providers, the overarching goal of QRIS is to alter parental preferences for high-quality care — such that they recognize its value and are willing to pay more for it-while encouraging competition between providers.

This paper provides four noteworthy results. First, implementation of QRIS induces families to use more non-parental child care, but economically disadvantaged and advantaged families appear to respond differently: the former is more likely to switch to informal modes of child care, while the latter is more likely to use formal care. Consistent with this pattern, QRIS has no effect on the labor supply of low-skilled mothers, but increases employment and wages among high-skilled mothers. Second, the supply of child care labor-as proxied by the number of new employees - increases following QRIS enactment. Moreover, there is some indication that the quality ratings are increasing 
the attractiveness of center-based child care employment, particularly among high-skilled women. Third, the evidence suggests that low-skilled and less experienced (i.e., younger) child care workers experience both rising compensation and turnover, while their high-skilled counterparts experience no such changes. Finally, QRIS - when operating alongside child care a wage compensation program - is estimated to increase the supply of child care, lower turnover, and increase earnings more so than in states where QRIS is operating without such a program.

Together, this evidence provides a basis for optimism and identifies areas of concern regarding the impact of QRIS on the child care market. There is a clear recognition in states' QRIS that a highly-skilled workforce is integral to the production of high-quality child care. Indeed, most states include staff qualifications - typically defined as teacher and director education levels, type of degree, and work experience - as an explicit component of the quality rating. In addition, states are increasingly providing child care staff with financial assistance and incentives to undertake further education and training (e.g., T.E.A.C.H Scholarships), paid curriculum planning and preparation time, and wage supplements (e.g., WAGE\$ and REWARD). Such benefits are of course designed to increase the quality of existing staff, but they also seek to increase the attractiveness of child care employment relative to other occupations, particularly among high-skilled individuals. The evidence presented in this paper indicates that the professional development components of QRIS, especially the wage compensation programs, may be working as intended. Specifically, I find that the supply of high-skilled labor-defined as individuals with at least some college education—increased following QRIS implementation, particularly within center-based child care settings.

On the other hand, that QRIS appears to have differential effects on the child care choices of disadvantaged and advantaged families is cause for concern. In particular, the ratings system may induce disadvantaged families to select lower-cost (and thus lower-quality) informal child care arrangements - a result at odds with the intended effect of QRIS. Two alternative explanations are consistent with this result. First, it is possible that the ratings system has revealed a set of quality- 
related attributes that low-income families either do not value or do not believe to be productive inputs to child development. In other words, armed with information about the programmatic elements that constitute a "high-quality" provider, such parents opt instead to search for child care with a different set of features (e.g., high levels of convenience or reliability). Second, insofar as higher-quality care is more costly to produce, and to the extent that QRIS participation leads providers to increase prices, the enactment of QRIS may have the effect of pricing low-income families out of the formal child care market. Such concerns are illustrated in Zellman and Perlman's (2008) interviews with state QRIS administrators, who note that parents have begun to associate the star-ratings with cost-of-care and, as a result, limit their search to lower-rated programs.

Assuming that QRIS places upward pressure on market prices-which in turn may decrease the utilization of formal care among low-income families - a potential policy response is to increase the availability and generosity of child care subsidies. However, given that parents view child care quality and quantity as substitutes, one concern is that providing support through programs like the Child Care Tax Credit or the Child Care and Development Fund, which lower the cost of purchasing child care at all levels of quality, may exacerbate the shift into informal care (Blau \& Hagy, 1998). To alleviate this problem, a child care subsidy whose value is greater when purchasing care provided by QRIS participants (or more highly-rated participants) may be preferable. 


\section{References}

Auger, A., Farkas, G., Burchinal, M., Duncan, G., \& Vandell, D. (2014). Preschool center care quality effects on academic achievement: An instrumental variables analysis. Developmental Psychology, 50, 2559-2571.

Bassok, D., Fitzpatrick, M., Loeb, S. \& Paglayan, A. (2013). The early childhood care and education workforce from 1990 through 2010: Changing dynamics and persistent concerns. Education Finance and Policy, 8, 581-601.

Blau, D. (1992). The child care labor market. Journal of Human Resources, 27, 9-39.

Blau, D. (2003). Do child care regulations affect the child care and labor markets? Journal of Policy Analysis and Management, 22, 443-465.

Blau, D. \& Hagy, A. (1998). The demand for quality in child care. Journal of Political Economy, 106, 104-146,

Boller, K., Paulsell, D., Del Grosso, P., Blair, R., Lundquist, E., Kassow, D., Kim, R., \& Raikes, A. (2015). Impacts of a child care quality rating and improvement system on child care quality. Early Childhood Research Quarterly, 30, 306-315.

Cryer, C. \& Burchinal, M. (1997). Parents as child care consumers. Early Childhood Research Quarterly, 12, 35-58.

Elicker, J., Langill, C., \& colleages. (2011). Evaluation of Paths to QUALITY, Indiana's Child Care Quality Rating and Improvement System: Final Report. West Lafayette, IN: Purdue University.

Harms, T., Cryer, D. \& Clifford, R. M. (2005). Early Childhood Environment Rating Scale-Revised Edition (ECERS-R), Updated. New York: Teachers College Press.

Harms, T., Cryer, D. \& Clifford, R. M. (2006). Infant/Toddler Environment Rating Scale-Revised Edition (ITERS-R), Updated. New York: Teachers College Press.

Harms, T., Cryer, D. \& Clifford, R. M. (2007). Family Child Care Environment Rating ScaleRevised Edition (FCCERS-R). New York: Teachers College Press.

Helbrun, S. \& Howes, C. (1996). Child care cost and quality: The future of children, financing child care. Los Angeles, CA: Center for the Future of Children.

Herbst, C.M. (2015). The rising cost of child care in the United States: A reassessment of the evidence. IZA Discussion Paper No. 9072. Bonn, Germany: Institute for the Study of Labor.

Herzenberg, S., Price, M., \& Bradley, D. (2005). Losing ground in early childhood education: Declining workforce qualifications in an expanding industry, 1979-2004. Washington, DC:

Economic Policy Institute. 
Hestenes, L., Kintner-Duffy, V., Wang, Y., La Paro, K., Mims, S., Crosby, D., Scott-Little, C., \& Cassidy, D. (2015). Comparisons among quality measures in child care settings: Understanding the use of multiple measures in North Carolina's QRIS and their links to social-emotional development in preschool children. Early Childhood Research Quarterly, 30, 199-214.

Hill, J., Waldfogel, J., \& Brooks-Gunn, J. (2002). Differential effects of high quality child care. Journal of Policy Analysis and Management, 21, 601-627.

Karoly, L. (2014). Validation studies for early learning and care quality rating and improvement systems: A review of the literature. WR-1051-DOEL. Santa Monica, CA: RAND Education and RAND Labor and Population.

Keys, T. D., Farkas, G., Burchinal, M. R., Duncan, G. J., Vandell, D. L., Li, W., Ruzek, E. A. \& Howes, C. (2013). Preschool Center Quality and School Readiness: Quality Effects and Variation by Demographic and Child Characteristics. Child Development, 84, 1171-1190.

Laughlin, L. (2010). Who's minding the kids? Child care Arrangements: Spring 2005/Summer 2006. Current Population Reports P70-121. Washington, DC: U.S. Census Bureau.

Mamedova, S. \& Redford, J. (2015). Early Childhood Program Participation, From the National Household Education Surveys Program of 2012 (NCES 2013-029.REV), National Center for Education Statistics, Institute of Education Sciences, U.S. Department of Education. Washington, DC.

Minnesota Department of Human Services. (2015). The Parent Aware Quality Rating and Improvement System: Increasing Accessibility for Families and Early Care and Education Programs. Legislative Report. St. Paul, MN: Children and Family Services Administration.

Mocan, N. (2007). Can Consumers Detect Lemons? An Empirical Investigation of Information Asymmetry in the Market for Child Care. Journal of Population Economics, 20, 507-531.

National Child Care Information Center (2006). Quality Rating Systems: Definition and Statewide Systems. Fairfax, VA: National Child Care Information Center.

National Survey of Early Care and Education Project Team (NSECE). (2014). Household search for and perceptions of early care and education: Initial findings from the National Survey of Early Care and Education (NSECE) (OPRE Report No. 2014-55a). Washington, DC: Office of Planning, Research and Evaluation, Administration for Children and Families, U.S. Department of Health and Human Services.

NICHD ECCRN \& Duncan, G. (2003). Modeling the impacts of child care quality on children's preschool cognitive development. Child Development, 74, 1454-1475.

Sabol, T., Hong, S., Pianta, R., \& Burchinal, M. (2013). Can rating pre-k programs predict children's learning? Science, 341, 845-846.

Sabol, T. \& Pianta, R. (2015). Validating Virginia's quality rating and improvement system among state-funded pre-kindergarten programs. Early Childhood Research Quarterly, 30, 183-198. 
Shen, J., W. Tackett, \& X. Ma. (2009). Second Evaluation Report for Palm Beach County Quality Improvement System. Palm Beach, CA: Children's Services Council of Palm Beach County.

Sirinides, P. (2010). Demonstrating Quality: Pennsylvania Keystone STARS: 2010 Program Report. Harrisburg, PA: Office of Child Development and Early Learning.

Tout, K. (2013). Look to the stars: Future directions for the evaluation of quality rating and improvement systems. Early Education and Development, 24, 71-78.

Tout, K., Starr, R., Soli, M., Moodie, S., Kirby, G., \& Boller, K. (2010). The child care quality rating system (QRS) assessment: Compendium of quality rating systems and evaluations. Child Trends and Mathematica Policy Research.

Tout, K., Starr, R., \& colleagues. (2011). Evaluation of Parent Aware: Minnesota's Quality Rating System Pilot: Final Evaluation Report. Minneapolis, MN: Child Trends.

Zellman, G. \& Perlman, M. (2008). Child-care quality rating and improvement systems in five pioneer states: Implementation issues and lessons learned. Santa Monica, CA: RAND Corporation.

Zellman, G., Perlman, M., \& colleagues. (2008). Assessing the Validity of the Qualistar Early Learning Quality Rating and Improvement System as a Tool for Improving Child-Care Quality. MG650. Santa Monica, CA: RAND Corporation. 
Figure 1: Number of States with a QRIS Implemented

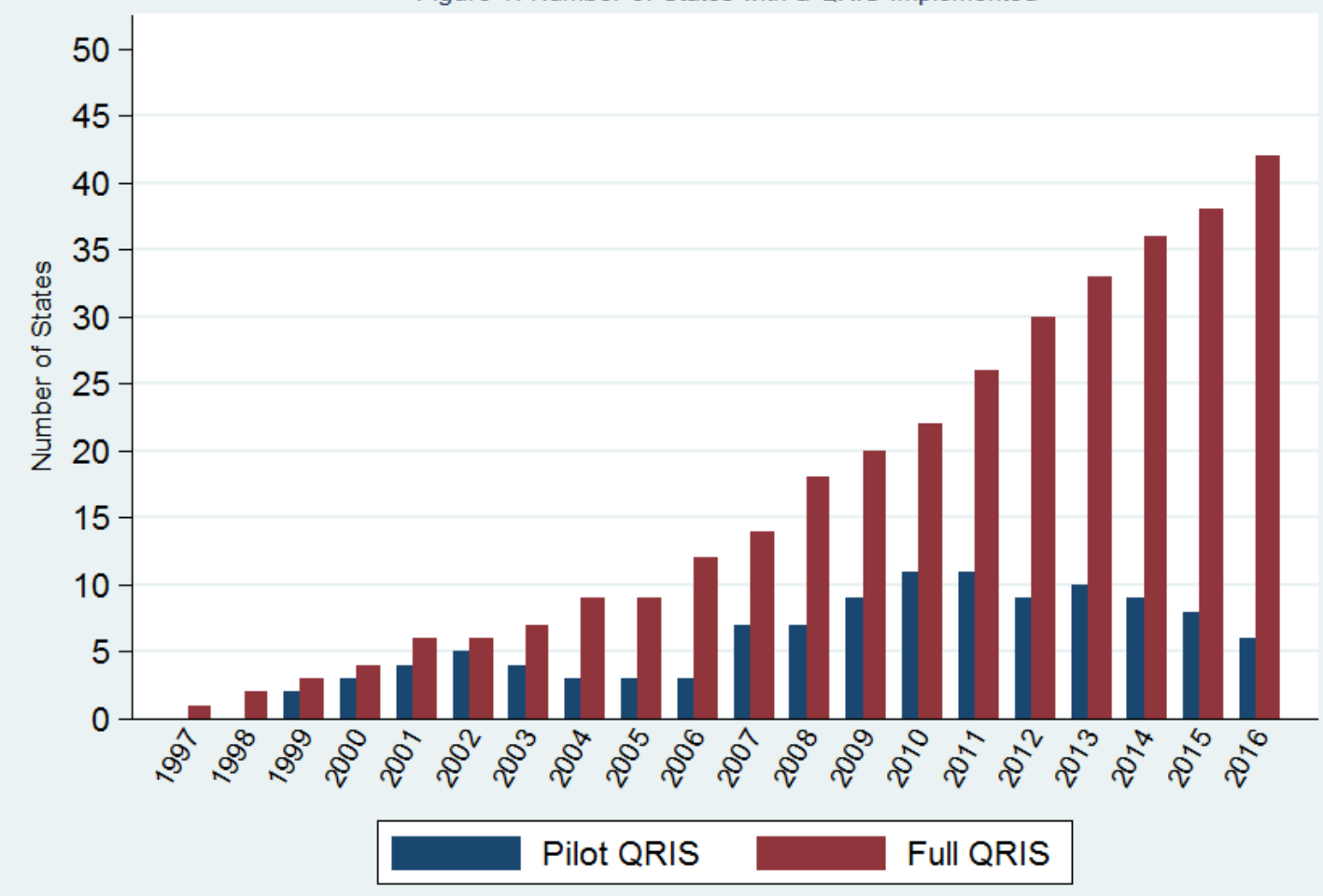


Figure 2: State-Specific Google Searches for QRIS Names (Oct 1, 2013 to Oct 1, 2016)

(a) Colorado Shines

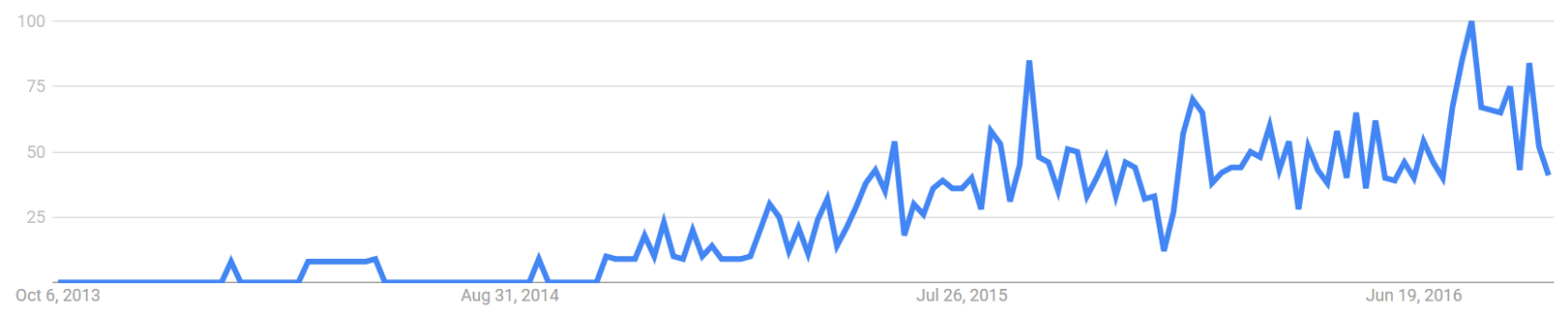

(b) ExceleRate Illinois

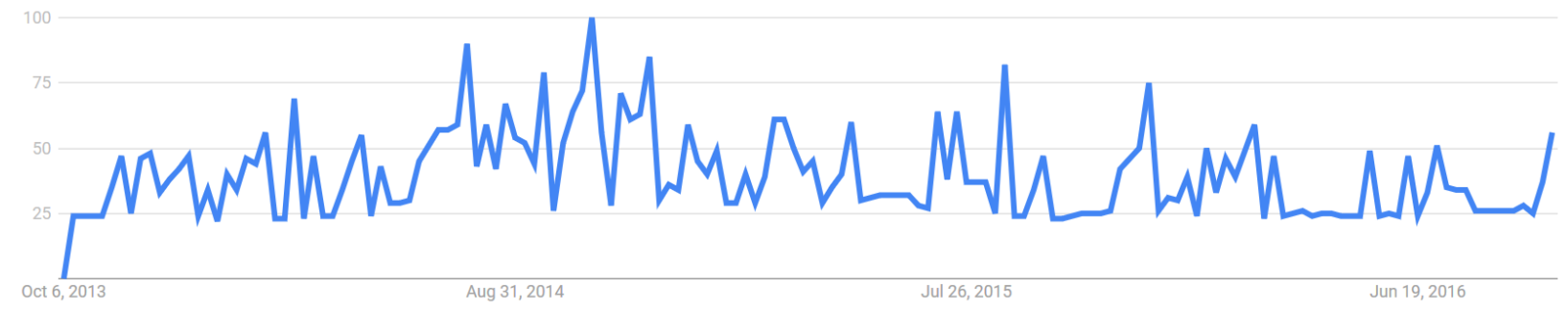

(c) Paths to Quality (Indiana)

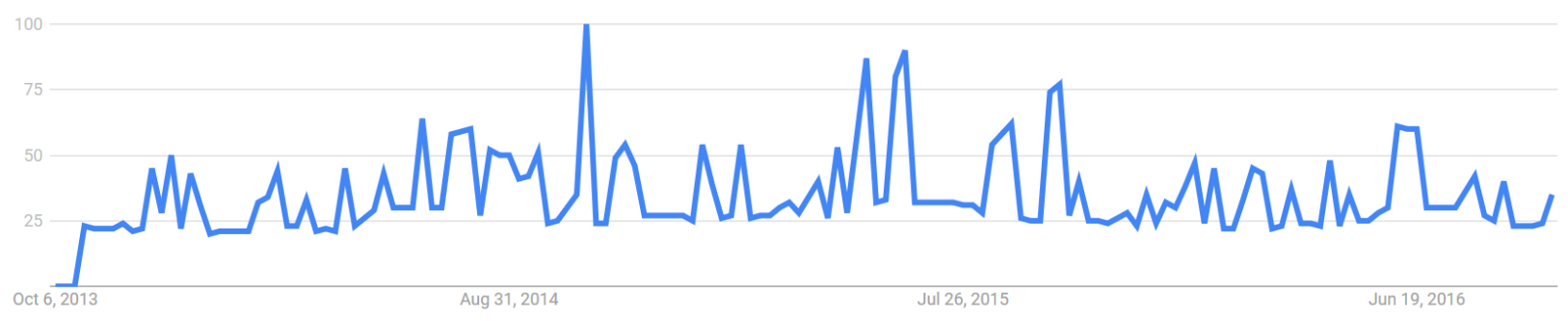

(d) Maryland EXCELS

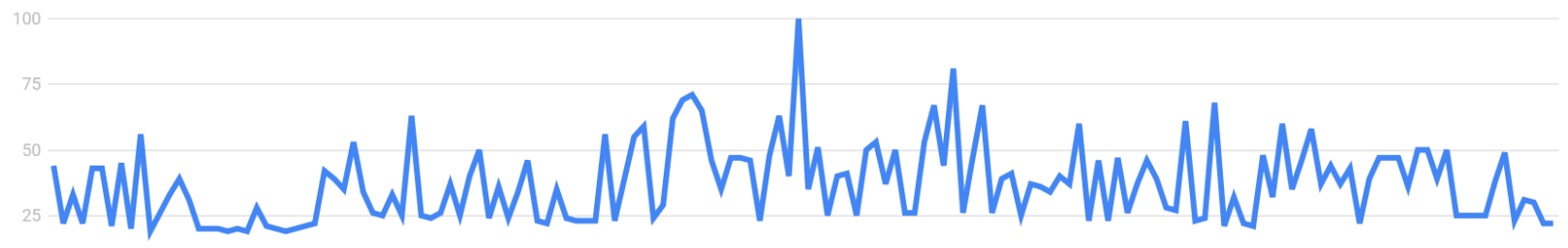

Oct $6 \overline{6,2013} \quad$ Aug 31, 2014 Jul 26, 2015

(e) Great Start to Quality (Michigan)

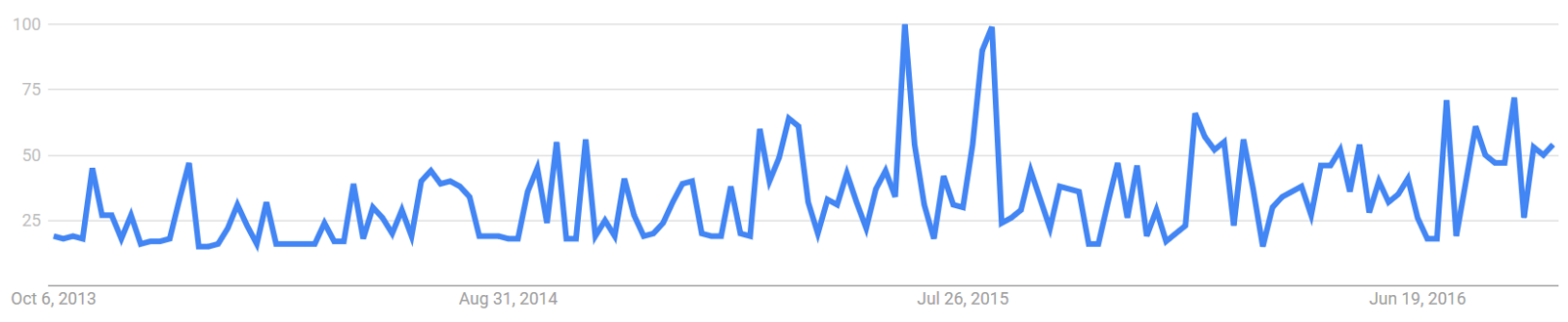

36 
(f) Parent Aware (Minnesota)

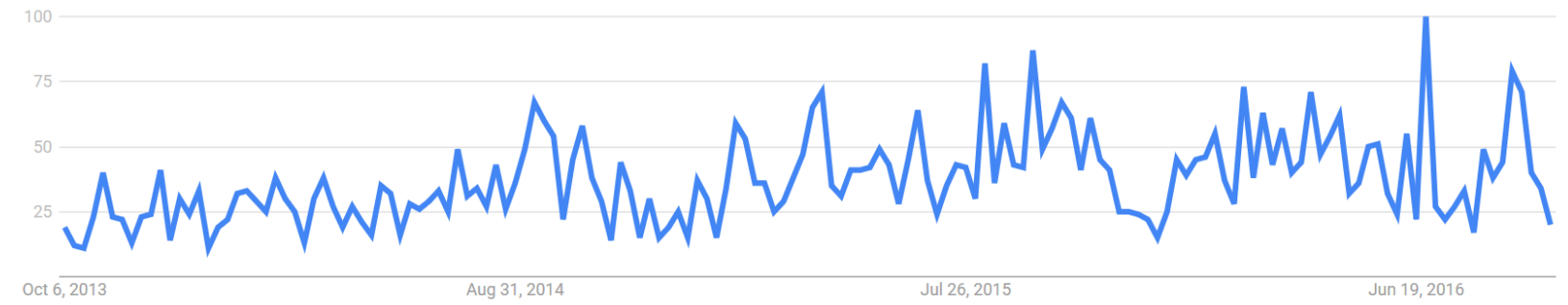

(g) Grow NJ Kids (New Jersey)

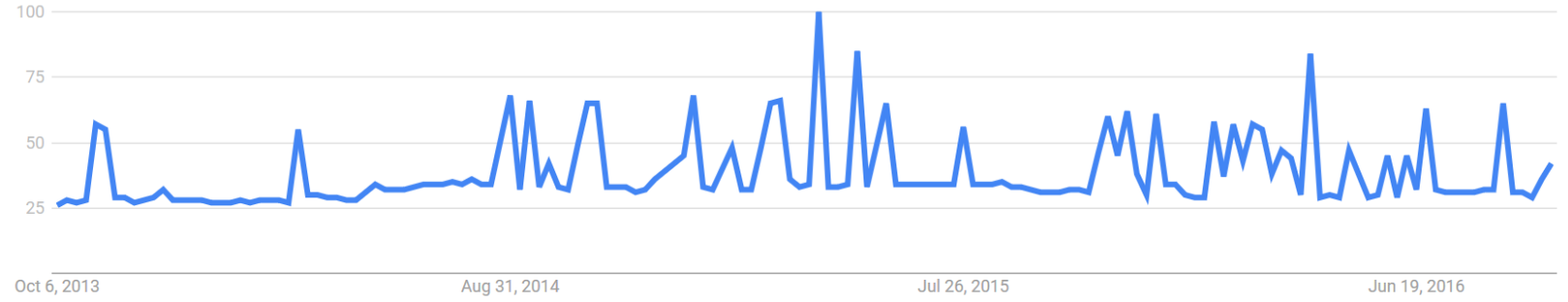

(h) Step Up To Quality (Ohio)

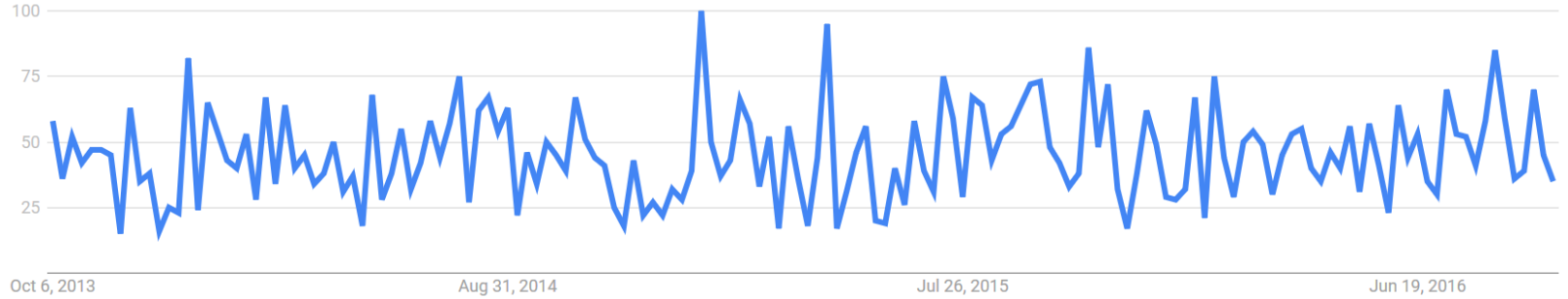

(i) Early Achievers (Washington)

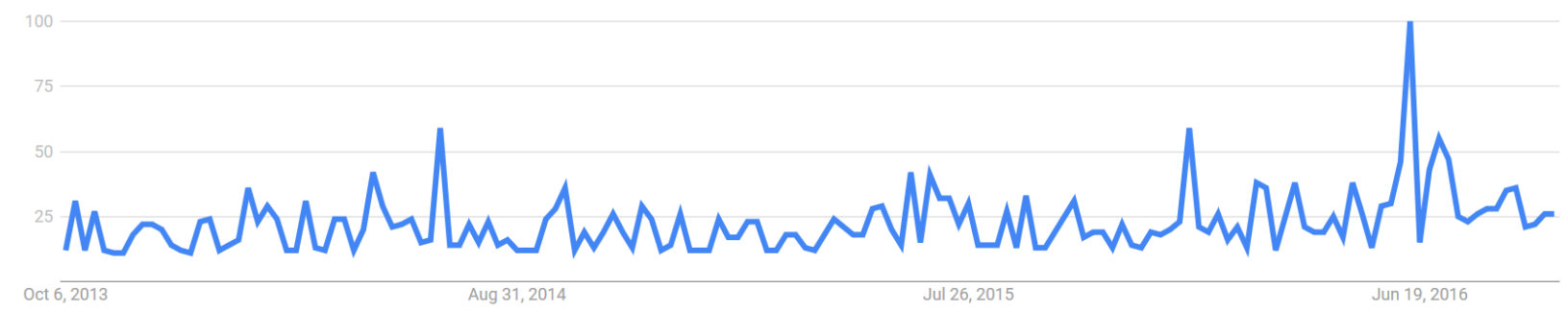

(j) Young Star (Wisconsin)

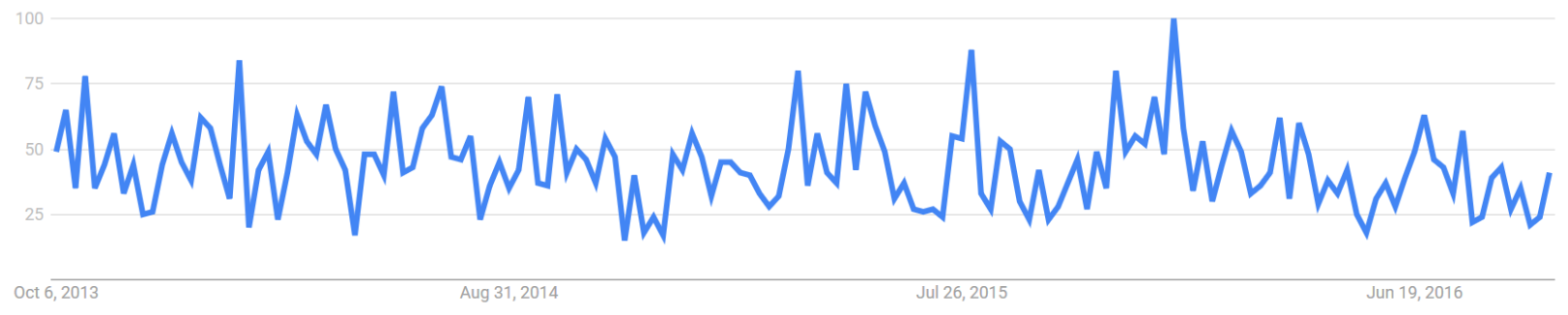




\section{Figure 3: Trends in Child Care Supply and Compensation Pre- and Post-Enactment of States' QRIS}
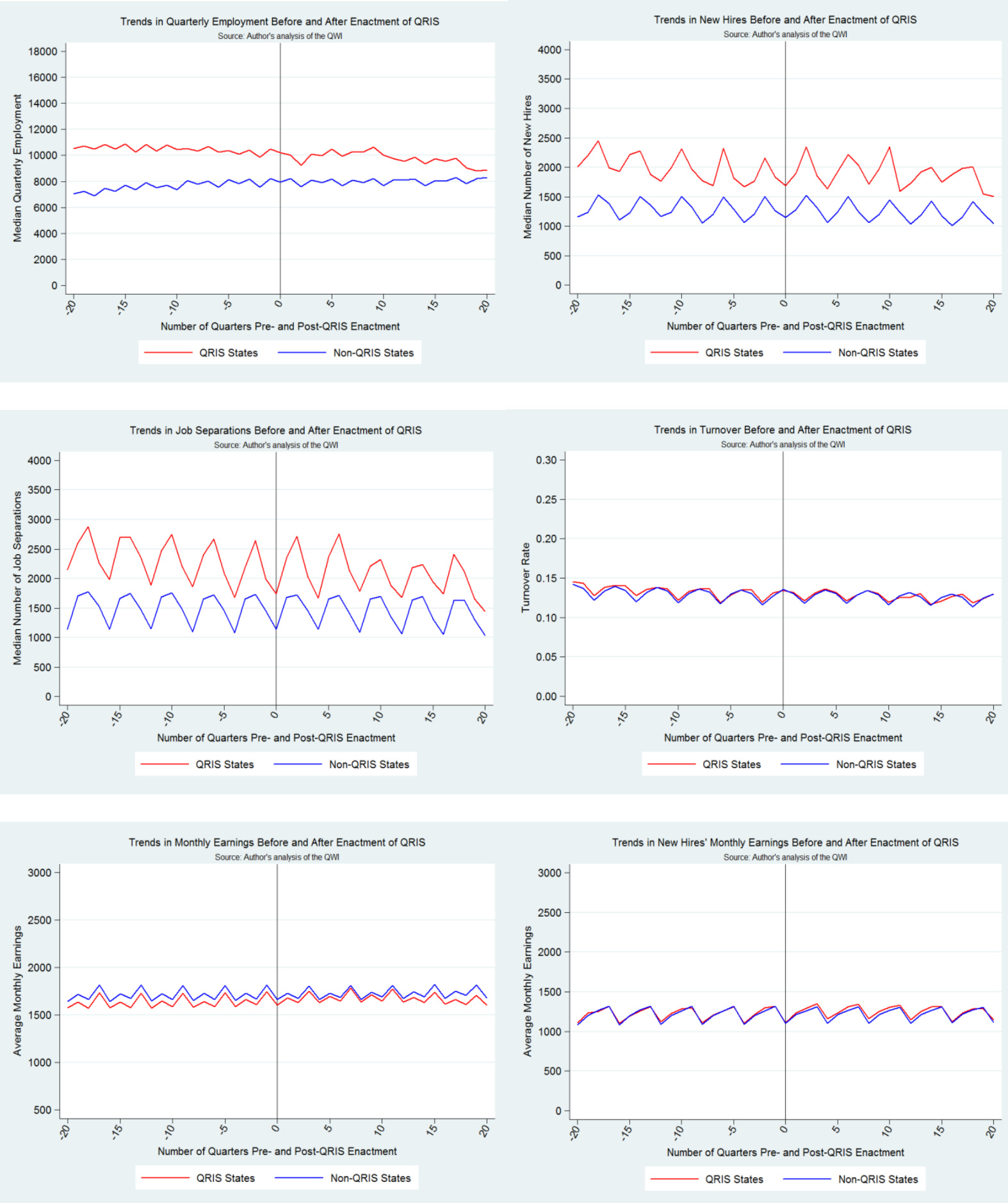
Figure 4: Differential Timing in the Effect of QRIS Enactment

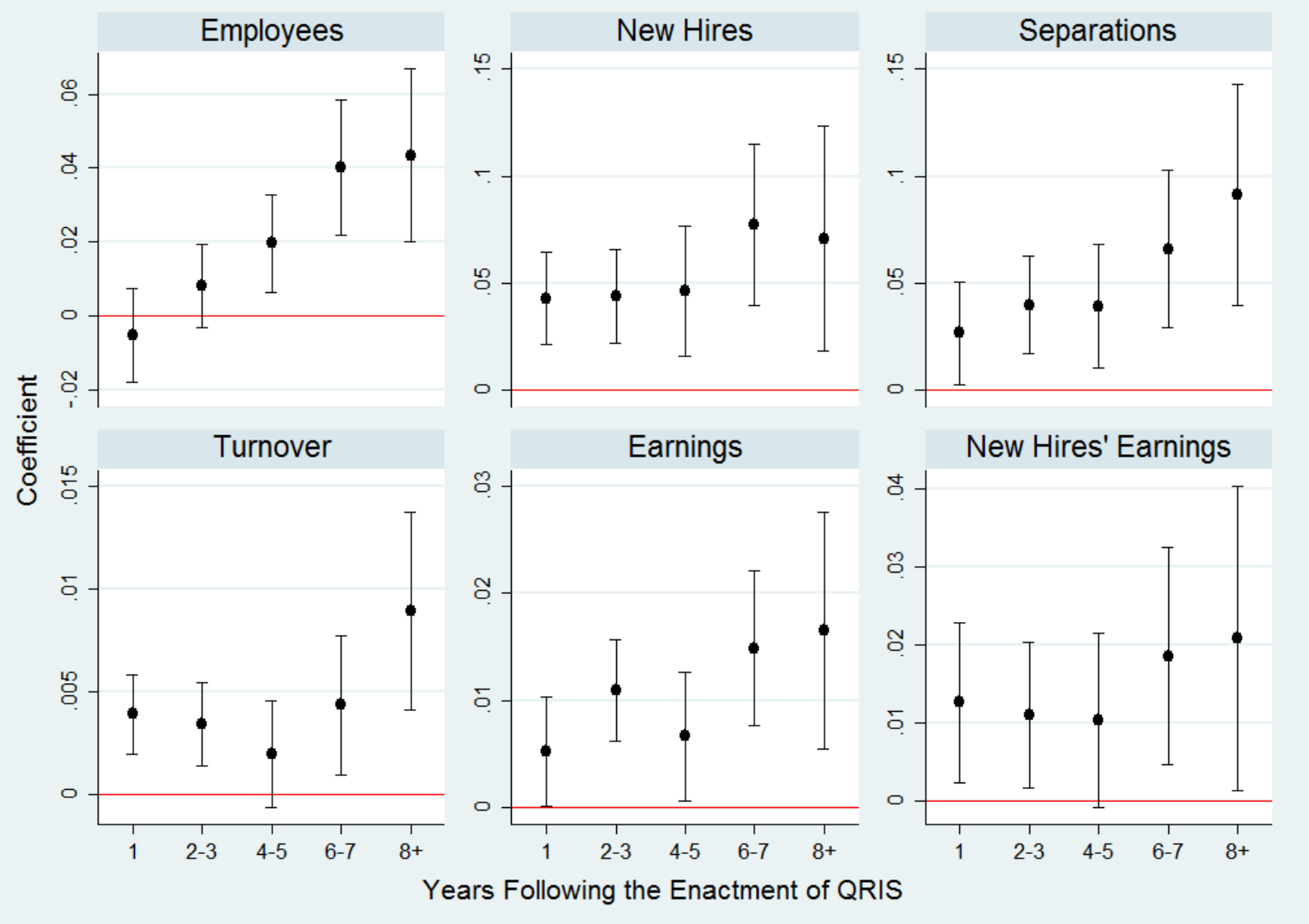


Table 1: Enactment Date of States' QRIS and Wage Supplement Programs

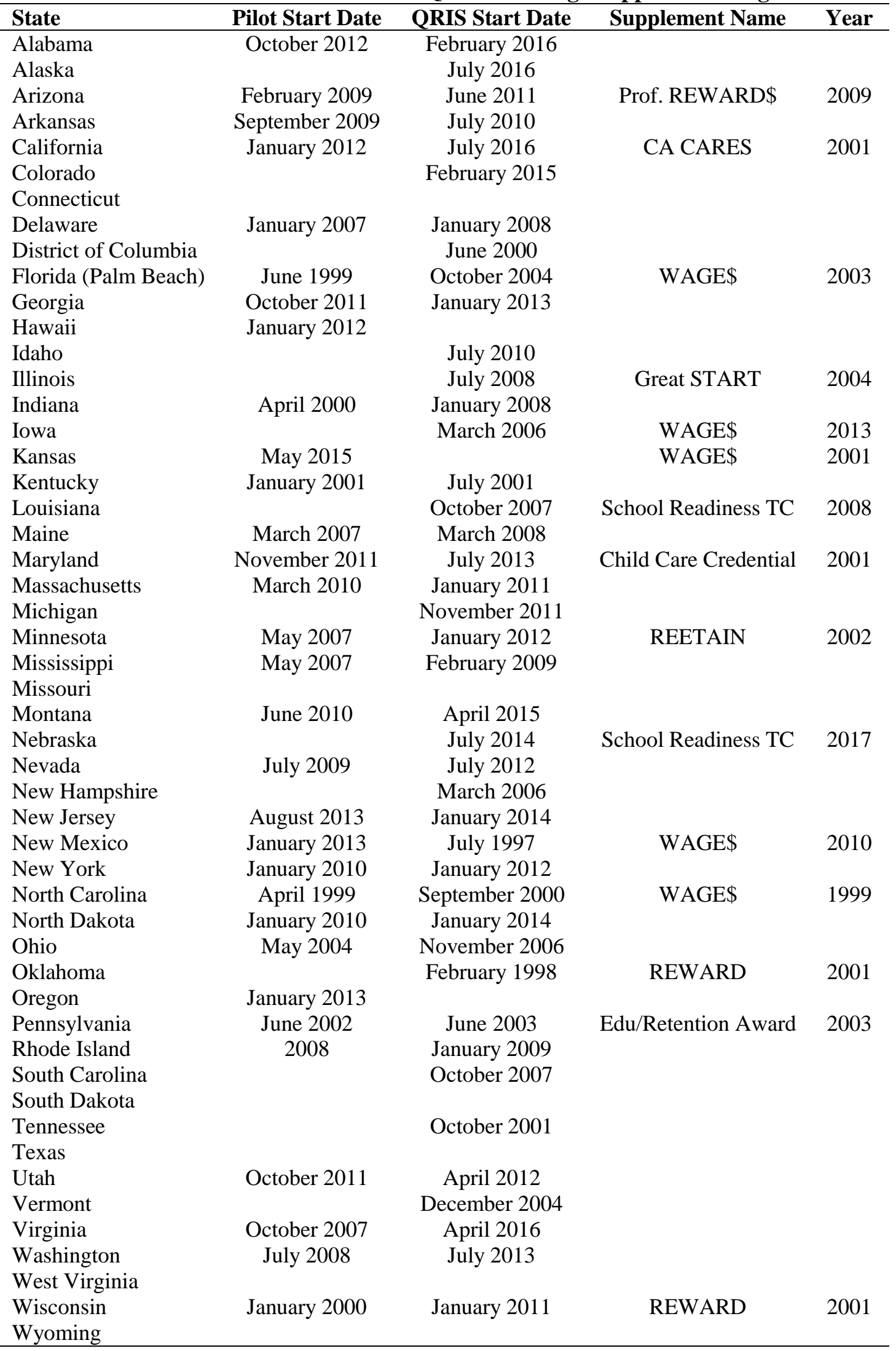


Table 2: Summary Statistics on the Child Care Choice and Maternal Employment Outcomes

\begin{tabular}{|c|c|c|c|}
\hline Outcome & $\begin{array}{c}\text { Full } \\
\text { Sample }\end{array}$ & $\begin{array}{l}\text { Low-Skilled } \\
\text { Sub-Sample }\end{array}$ & $\begin{array}{l}\text { High-Skilled } \\
\text { Sub-Sample }\end{array}$ \\
\hline \multicolumn{4}{|c|}{ Panel A: National Household Education Survey (2005 and 2012) } \\
\hline Parent care $(\%)$ & $\begin{array}{c}0.365 \\
(0.482)\end{array}$ & $\begin{array}{c}0.433 \\
(0.496)\end{array}$ & $\begin{array}{c}0.275 \\
(0.446)\end{array}$ \\
\hline Relative care $(\%)$ & $\begin{array}{c}0.182 \\
(0.386)\end{array}$ & $\begin{array}{c}0.201 \\
(0.401)\end{array}$ & $\begin{array}{c}0.151 \\
(0.358)\end{array}$ \\
\hline Non-relative care $(\%)$ & $\begin{array}{c}0.032 \\
(0.175)\end{array}$ & $\begin{array}{l}0.016 \\
(0.125)\end{array}$ & $\begin{array}{c}0.054 \\
(0.227)\end{array}$ \\
\hline Family-based care $(\%)$ & $\begin{array}{c}0.087 \\
(0.282)\end{array}$ & $\begin{array}{l}0.076 \\
(0.266)\end{array}$ & $\begin{array}{l}0.105 \\
(0.306)\end{array}$ \\
\hline Center-based care $(\%)$ & $\begin{array}{c}0.334 \\
(0.472)\end{array}$ & $\begin{array}{c}0.274 \\
(0.446)\end{array}$ & $\begin{array}{c}0.415 \\
(0.492)\end{array}$ \\
\hline Weekly hours of child care use (no.) & $\begin{array}{c}17.54 \\
(18.93)\end{array}$ & $\begin{array}{l}15.39 \\
(18.72)\end{array}$ & $\begin{array}{c}20.28 \\
(18.64)\end{array}$ \\
\hline Pays for child care $(\%)$ & $\begin{array}{c}0.427 \\
(0.495)\end{array}$ & $\begin{array}{l}0.321 \\
(0.467)\end{array}$ & $\begin{array}{c}0.580 \\
(0.494)\end{array}$ \\
\hline Real weekly child care expenditure $(\$)$ & $\begin{array}{c}56.42 \\
(142.15)\end{array}$ & $\begin{array}{c}31.02 \\
(74.09)\end{array}$ & $\begin{array}{c}92.10 \\
(198.81)\end{array}$ \\
\hline Real hourly child care expenditure (\$) & $\begin{array}{c}2.61 \\
(9.11)\end{array}$ & $\begin{array}{c}1.57 \\
(6.56)\end{array}$ & $\begin{array}{c}4.06 \\
(11.78)\end{array}$ \\
\hline Panel B: Current Population Survey (1) & & & \\
\hline Maternal employment (\%) & $\begin{array}{c}0.668 \\
(0.471)\end{array}$ & $\begin{array}{l}0.575 \\
(0.494)\end{array}$ & $\begin{array}{c}0.735 \\
(0.441)\end{array}$ \\
\hline Annual weeks of work (no.) & $\begin{array}{c}29.04 \\
(23.60)\end{array}$ & $\begin{array}{l}23.66 \\
(23.64)\end{array}$ & $\begin{array}{c}32.94 \\
(22.79)\end{array}$ \\
\hline Weekly hours of work (no.) & $\begin{array}{c}23.28 \\
(18.90)\end{array}$ & $\begin{array}{l}19.95 \\
(18.94)\end{array}$ & $\begin{array}{c}25.70 \\
(18.50)\end{array}$ \\
\hline Real hourly wage (\$) & $\begin{array}{c}15.11 \\
(64.35)\end{array}$ & $\begin{array}{c}8.62 \\
(54.43)\end{array}$ & $\begin{array}{c}19.82 \\
(70.30)\end{array}$ \\
\hline
\end{tabular}

Source: Author's analysis of the 2005 and 2012 NHES and the 1992-2015 CPS.

Notes: Standard deviations are in parentheses. All dollar amounts are adjusted for inflation. The child care utilization variables reflect current participation in the primary arrangement. 
Table 3: Summary Statistics on the Child Care Labor Market Outcomes

\begin{tabular}{|c|c|c|c|}
\hline Outcome & $\begin{array}{c}\text { Full } \\
\text { Sample }\end{array}$ & $\begin{array}{l}\text { Low-Skilled } \\
\text { Sub-Sample }\end{array}$ & $\begin{array}{l}\text { High-Skilled } \\
\text { Sub-Sample }\end{array}$ \\
\hline \multicolumn{4}{|c|}{ Panel A: Current Population Survey (1992-2015) } \\
\hline Home-based child care worker $(\%)$ & $\begin{array}{c}0.009 \\
(0.094)\end{array}$ & $\begin{array}{c}0.011 \\
(0.102)\end{array}$ & $\begin{array}{c}0.008 \\
(0.087)\end{array}$ \\
\hline Center-based child care worker (\%) & $\begin{array}{c}0.013 \\
(0.115)\end{array}$ & $\begin{array}{c}0.012 \\
(0.109)\end{array}$ & $\begin{array}{c}0.014 \\
(0.119)\end{array}$ \\
\hline School-based child care worker $(\%)$ & $\begin{array}{c}0.013 \\
(0.111)\end{array}$ & $\begin{array}{c}0.009 \\
(0.094)\end{array}$ & $\begin{array}{c}0.015 \\
(0.123)\end{array}$ \\
\hline Other female workers $(\%)$ & $\begin{array}{c}0.703 \\
(0.457)\end{array}$ & $\begin{array}{c}0.617 \\
(0.486)\end{array}$ & $\begin{array}{c}0.769 \\
(0.421)\end{array}$ \\
\hline Real hourly wage, child care workers $(\$)$ & $\begin{array}{c}13.35 \\
(41.71)\end{array}$ & $\begin{array}{l}10.87 \\
(28.91)\end{array}$ & $\begin{array}{c}14.99 \\
(48.25)\end{array}$ \\
\hline Real hourly wage, other female workers $(\$)$ & $\begin{array}{c}21.53 \\
(109.02)\end{array}$ & $\begin{array}{c}15.66 \\
(72.28)\end{array}$ & $\begin{array}{c}25.15 \\
(126.38)\end{array}$ \\
\hline \multicolumn{4}{|c|}{ Panel B: Quarterly Workforce Indicators (1993-2015) } \\
\hline Total employment (no.) & $\begin{array}{c}13312 \\
(13341)\end{array}$ & $\begin{array}{c}1397 \\
(1841)\end{array}$ & $\begin{array}{c}2022 \\
(2264)\end{array}$ \\
\hline New hires (no.) & $\begin{array}{c}2650 \\
(2760)\end{array}$ & $\begin{array}{l}233 \\
(310)\end{array}$ & $\begin{array}{l}285 \\
(300)\end{array}$ \\
\hline Job separations (no.) & $\begin{array}{c}3003 \\
(3095)\end{array}$ & $\begin{array}{c}276 \\
(355)\end{array}$ & $\begin{array}{c}353 \\
(369)\end{array}$ \\
\hline Turnover rate $(\%)$ & $\begin{array}{c}0.136 \\
(0.029)\end{array}$ & $\begin{array}{c}0.123 \\
(0.035)\end{array}$ & $\begin{array}{c}0.109 \\
(0.027)\end{array}$ \\
\hline Real monthly earnings $(\$)$ & $\begin{array}{l}1651 \\
(268)\end{array}$ & $\begin{array}{l}1526 \\
(228)\end{array}$ & $\begin{array}{l}2183 \\
(384)\end{array}$ \\
\hline Real new hires' monthly earnings (\$) & $\begin{array}{l}1036 \\
(239) \\
\end{array}$ & $\begin{array}{l}1076 \\
(267) \\
\end{array}$ & $\begin{array}{l}1291 \\
(315) \\
\end{array}$ \\
\hline
\end{tabular}

Source: Author's analysis of the 1992-2015 CPS and the 1993-2015 QWI.

Notes: Standard deviations are in parentheses. All dollar amounts are adjusted for inflation. In Panel A, the low-skilled subsample includes individuals with no more than a high school degree, while the high-skilled sub-sample includes individuals with more than a high school degree. In panel B, the low-skilled sub-sample includes employees with less than a high school degree, while the high-skilled sub-sample includes employees with a BA degree or more. 
Table 4: Effects of QRIS on Families' Child Care Choices

\begin{tabular}{|c|c|c|c|c|c|c|c|c|}
\hline & Relative & $\begin{array}{c}\text { Non- } \\
\text { Relative }\end{array}$ & $\begin{array}{c}\text { Family- } \\
\text { Based }\end{array}$ & $\begin{array}{c}\text { Center- } \\
\text { Based }\end{array}$ & $\begin{array}{c}\text { Hours of } \\
\text { Use }\end{array}$ & $\begin{array}{c}\text { Pays for } \\
\text { Care } \\
\end{array}$ & $\begin{array}{l}\text { ln(weekly } \\
\text { expenses) }\end{array}$ & $\begin{array}{l}\text { ln(hourly } \\
\text { expenses) }\end{array}$ \\
\hline \multicolumn{9}{|c|}{ Panel A: Full Sample } \\
\hline QRIS & $\begin{array}{l}1.292 * * * \\
(0.103)\end{array}$ & $\begin{array}{c}1.240 \\
(0.191)\end{array}$ & $\begin{array}{c}1.163 \\
(0.126)\end{array}$ & $\begin{array}{c}1.101 \\
(0.082)\end{array}$ & $\begin{array}{l}2.172 * * * \\
(0.645)\end{array}$ & $\begin{array}{l}-0.010 \\
(0.010)\end{array}$ & $\begin{array}{l}-0.019 \\
(0.044)\end{array}$ & $\begin{array}{l}-0.020 \\
(0.021)\end{array}$ \\
\hline \multicolumn{9}{|c|}{ Panel B: Low-Skilled Sub-Sample } \\
\hline QRIS & $\begin{array}{l}1.314^{* *} \\
(0.140)\end{array}$ & $\begin{array}{c}1.026 \\
(0.311)\end{array}$ & $\begin{array}{c}1.091 \\
(0.139)\end{array}$ & $\begin{array}{c}1.111 \\
(0.111)\end{array}$ & $\begin{array}{l}2.529 * * \\
(1.059)\end{array}$ & $\begin{array}{l}-0.042 * * * \\
(0.013)\end{array}$ & $\begin{array}{l}-0.162 * * * \\
(0.053)\end{array}$ & $\begin{array}{l}-0.087 * * * \\
(0.023)\end{array}$ \\
\hline \multicolumn{9}{|c|}{ Panel C: High-Skilled Sub-Sample } \\
\hline QRIS & $\begin{array}{c}1.216 \\
(0.166) \\
\end{array}$ & $\begin{array}{l}1.586^{* * *} \\
(0.292) \\
\end{array}$ & $\begin{array}{c}1.419 * \\
(0.279)\end{array}$ & $\begin{array}{c}1.201 * \\
(0.133) \\
\end{array}$ & $\begin{array}{l}2.130 * * \\
(0.922)\end{array}$ & $\begin{array}{l}0.054 * * * \\
(0.017)\end{array}$ & $\begin{array}{l}0.268 * * * \\
(0.075)\end{array}$ & $\begin{array}{l}0.096^{* * *} \\
(0.035)\end{array}$ \\
\hline
\end{tabular}

Source: Author's analysis of the 2005 and 2012 NHES

Notes: Standard errors, which are adjusted for state-year clustering, are displayed in parentheses. The full sample analysis is based on 14,270 observations. The lowskilled sub-sample includes mothers with a high school degree or less $(\mathrm{N}=8,127)$. The high-skilled sub-sample include mothers with more than a high school degree $(\mathrm{N}=5,732)$. Coefficients from the multinomial logit model of families' child care choices are odds ratios. The base category includes children using exclusively parent care. All models include the individual- and state-level controls, state fixed effects, and year effects. ***,**, and * indicate statistical significance at the 0.01 , 0.05 , and 0.10 levels, respectively. 
Table 5: Effects of QRIS on Mothers' Employment

\begin{tabular}{|c|c|c|c|c|}
\hline & Any Work & Weeks of Work & Hours of Work & In(hourly wage) \\
\hline \multicolumn{5}{|c|}{ Panel A: Full Sample } \\
\hline$Q R I S$ & $\begin{array}{l}0.009 * * \\
(0.004)\end{array}$ & $\begin{array}{l}0.700 * * * \\
(0.269)\end{array}$ & $\begin{array}{l}0.745^{* * *} \\
(0.233)\end{array}$ & $\begin{array}{l}0.023 * * \\
(0.011)\end{array}$ \\
\hline \multicolumn{5}{|c|}{ Panel B: Low-Skilled Sub-Sample } \\
\hline$Q R I S$ & $\begin{array}{l}-0.007 \\
(0.006)\end{array}$ & $\begin{array}{c}-0.718 \\
(0.490)\end{array}$ & $\begin{array}{l}-0.226 \\
(0.403)\end{array}$ & $\begin{array}{c}-0.012 \\
(0.017)\end{array}$ \\
\hline \multicolumn{5}{|c|}{ Panel C: High-Skilled Sub-Sample } \\
\hline$Q R I S$ & $\begin{array}{l}0.017 \text { *** } \\
(0.004)\end{array}$ & $\begin{array}{l}1.398 * * * \\
(0.296)\end{array}$ & $\begin{array}{l}1.187 * * * \\
(0.254)\end{array}$ & $\begin{array}{l}0.040 * * * \\
(0.014)\end{array}$ \\
\hline
\end{tabular}

Source: Author's analysis of the 1992-2015 CPS

Notes: Standard errors, which are adjusted for state-year clustering, are displayed in parentheses. The full sample analysis is based on 259,005 observations. The low-skilled sub-sample includes mothers with a high school degree or less $(\mathrm{N}=108,915)$. The high-skilled sub-sample include mothers with more than a high school degree $(\mathrm{N}=150,090)$.

All models include the individual- and state-level controls, state fixed effects, and year effects. ***, **, and $*$ indicate statistical significance at the $0.01,0.05$, and 0.10 levels, respectively. 
Table 6: Effects of QRIS on Child Care Labor Market Outcomes

\begin{tabular}{|c|c|c|c|c|}
\hline & $\begin{array}{c}\text { Home-Based } \\
\text { Worker }\end{array}$ & $\begin{array}{c}\text { Center-Based } \\
\text { Worker }\end{array}$ & $\begin{array}{c}\text { School-Based } \\
\text { Worker }\end{array}$ & ln(hourly wage) \\
\hline \multicolumn{5}{|c|}{ Panel A: Full Sample } \\
\hline$Q R I S$ & $\begin{array}{c}1.026 \\
(0.042)\end{array}$ & $\begin{array}{l}1.103 * * * \\
(0.034)\end{array}$ & $\begin{array}{c}0.990 \\
(0.033)\end{array}$ & $\begin{array}{c}0.001 \\
(0.011)\end{array}$ \\
\hline \multicolumn{5}{|c|}{ Panel B: Low-Skilled Sub-Sample } \\
\hline QRIS & $\begin{array}{c}1.063 \\
(0.059)\end{array}$ & $\begin{array}{c}1.060 \\
(0.052)\end{array}$ & $\begin{array}{c}0.937 \\
(0.055)\end{array}$ & $\begin{array}{c}0.021 \\
(0.018)\end{array}$ \\
\hline \multicolumn{5}{|c|}{ Panel C: High-Skilled Sub-Sample } \\
\hline$Q R I S$ & $\begin{array}{c}0.993 \\
(0.053) \\
\end{array}$ & $\begin{array}{l}1.146 * * * \\
(0.044)\end{array}$ & $\begin{array}{c}1.037 \\
(0.040) \\
\end{array}$ & $\begin{array}{l}-0.010 \\
(0.014)\end{array}$ \\
\hline
\end{tabular}

Source: Author's analysis of the 1992-2015 CPS

Notes: Standard errors, which are adjusted for state-year clustering, are displayed in parentheses. The lowskilled sub-sample includes mothers with a high school degree or less. The high-skilled sub-sample include mothers with more than a high school degree. Coefficients from the multinomial logit model of women's child care sectoral choices are odds ratios. The base category includes non-working women. The full sample analysis of sectoral choices includes 1,365,519 observations, while the analyses in Panels B and C include 594,543 and 770,976 observations, respectively. The full sample analysis of hourly wages includes 47,431 observations, while the analyses in Panels B and C include 18,816 and 28,615 observations, respectively. All models include the individual- and state-level controls, state fixed effects, and year effects. ***,**, and * indicate statistical significance at the $0.01,0.05$, and 0.10 levels, respectively. 
Table 7: Effects of QRIS on Child Care Supply and Compensation

\begin{tabular}{|c|c|c|c|c|c|c|}
\hline & $\begin{array}{c}\ln (\text { employees per } \\
\text { child ages } 0-5)\end{array}$ & $\begin{array}{c}\text { In(new hires per } \\
\text { child ages } 0-5)\end{array}$ & $\begin{array}{l}\text { In(job separations } \\
\text { per child ages } 0-5)\end{array}$ & $\begin{array}{c}\text { Turnover } \\
\text { Rate }\end{array}$ & $\begin{array}{l}\text { ln(monthly } \\
\text { earnings) }\end{array}$ & $\begin{array}{c}\text { In(new hires' } \\
\text { monthly earnings) }\end{array}$ \\
\hline \multicolumn{7}{|c|}{ Panel A: All Employees } \\
\hline \multirow[t]{2}{*}{ QRIS } & 0.000 & $0.040 * * *$ & $0.026 * *$ & $0.002 * *$ & $0.007 * * *$ & $0.010 * *$ \\
\hline & $(0.006)$ & $(0.011)$ & $(0.012)$ & $(0.001)$ & $(0.002)$ & $(0.005)$ \\
\hline \multicolumn{7}{|c|}{ Panel B: Employees with Less than a High School Degree } \\
\hline QRIS & 0.005 & $0.051 * * *$ & $0.030 * *$ & $0.003 * *$ & $0.007 * * *$ & 0.008 \\
\hline \multicolumn{7}{|c|}{ Panel C: Employees with a High School Degree/GED } \\
\hline \multirow[t]{2}{*}{ QRIS } & 0.003 & $0.045^{* * *}$ & $0.028 * *$ & $0.002 * *$ & $0.007 * * *$ & 0.005 \\
\hline & $(0.006)$ & $(0.011)$ & $(0.012)$ & $(0.001)$ & $(0.002)$ & $(0.005)$ \\
\hline \multicolumn{7}{|c|}{ Panel D:Employees with Some College/Associate's Degree } \\
\hline QRIS & -0.001 & $0.040 * * *$ & $0.024 * *$ & $0.002 *$ & $0.008 * * *$ & 0.008 \\
\hline \multicolumn{7}{|c|}{ Panel E: Employees with a Bachelor's Degree or More } \\
\hline \multirow[t]{2}{*}{ QRIS } & -0.001 & $0.034 * * *$ & $0.022 *$ & 0.001 & 0.002 & 0.005 \\
\hline & $(0.006)$ & $(0.011)$ & $(0.012)$ & $(0.001)$ & $(0.003)$ & $(0.007)$ \\
\hline \multicolumn{7}{|c|}{ Panel F: Employees Ages 24 and Younger } \\
\hline \multirow[t]{2}{*}{ QRIS } & 0.003 & $0.040 * * *$ & $0.030 * *$ & $0.003 * *$ & $0.009 * * *$ & $0.013 * * *$ \\
\hline & $(0.008)$ & $(0.012)$ & $(0.012)$ & $(0.001)$ & $(0.003)$ & $(0.004)$ \\
\hline
\end{tabular}

Source: Author's analysis of the 1993-2015 QWI

Notes: Standard errors, which are adjusted for state-year clustering, are displayed in parentheses. All models include the state-level controls, state fixed effects, quarter*year effects, and state-specific linear time trends. ***,**, and * indicate statistical significance at the $0.01,0.05$, and 0.10 levels, respectively. 
Table 8: Effects of QRIS and Wage Supplement Programs on Child Care Supply and Compensation

\begin{tabular}{|c|c|c|c|c|c|c|}
\hline & $\begin{array}{l}\text { In(employees per } \\
\text { child ages } 0-5)\end{array}$ & $\begin{array}{l}\text { In(new hires per } \\
\text { child ages } 0-5)\end{array}$ & $\begin{array}{l}\text { In(job separations } \\
\text { per child ages } 0-5)\end{array}$ & $\begin{array}{l}\text { Turnover } \\
\text { Rate }\end{array}$ & $\begin{array}{l}\text { In(monthly } \\
\text { earnings })\end{array}$ & $\begin{array}{c}\text { In(new hires' } \\
\text { monthly earnings) }\end{array}$ \\
\hline QRIS_ONLY & $\begin{array}{l}-0.011 \\
(0.008)\end{array}$ & $\begin{array}{l}0.049 * * * \\
(0.011)\end{array}$ & $\begin{array}{l}0.040 * * * \\
(0.012)\end{array}$ & $\begin{array}{l}0.004 * * * \\
(0.001)\end{array}$ & $\begin{array}{c}0.002 \\
(0.003)\end{array}$ & $\begin{array}{c}0.007 \\
(0.005)\end{array}$ \\
\hline COMP_ONLY & $\begin{array}{c}0.006 \\
(0.011)\end{array}$ & $\begin{array}{l}-0.039 * * \\
(0.019)\end{array}$ & $\begin{array}{l}-0.038 * * \\
(0.018)\end{array}$ & $\begin{array}{l}-0.006 * * * \\
(0.002)\end{array}$ & $\begin{array}{l}0.020 * * * \\
(0.004)\end{array}$ & $\begin{array}{l}0.019 * * * \\
(0.007)\end{array}$ \\
\hline BOTH & $\begin{array}{l}0.019 * \\
(0.011)\end{array}$ & $\begin{array}{c}0.001 \\
(0.022)\end{array}$ & $\begin{array}{l}-0.019 \\
(0.022)\end{array}$ & $\begin{array}{l}-0.004 * * \\
(0.002)\end{array}$ & $\begin{array}{l}0.027 * * * \\
(0.004)\end{array}$ & $\begin{array}{l}0.028 * * * \\
(0.009)\end{array}$ \\
\hline $\begin{array}{l}\text { Ho: } \beta^{\text {QRIS_ONLY }}= \\
\beta^{\text {COMP_ONLY }}\end{array}$ & 0.186 & 0.000 & 0.000 & 0.000 & 0.000 & 0.133 \\
\hline $\begin{array}{l}\text { Ho: } \beta^{\text {QRIS_ONLY }}= \\
\beta^{\text {BOTH }}\end{array}$ & 0.016 & 0.036 & 0.013 & 0.000 & 0.000 & 0.028 \\
\hline
\end{tabular}


Table 9: Falsification Test

\begin{tabular}{|c|c|c|c|c|c|c|}
\hline & $\begin{array}{c}\ln (\text { employees per } \\
\text { child ages } 0-5)\end{array}$ & $\begin{array}{c}\ln (\text { new hires per } \\
\text { child ages } 0-5)\end{array}$ & $\begin{array}{l}\text { In(job separations } \\
\text { per child ages } 0-5)\end{array}$ & $\begin{array}{c}\text { Turnover } \\
\text { Rate }\end{array}$ & $\begin{array}{l}\ln (\text { monthly } \\
\text { earnings) }\end{array}$ & $\begin{array}{c}\text { In(new hires' } \\
\text { monthly earnings) }\end{array}$ \\
\hline $\begin{array}{l}5 \text { years } \\
\text { pre-QRIS }\end{array}$ & $\begin{array}{l}-0.003 \\
(0.008)\end{array}$ & $\begin{array}{c}0.001 \\
(0.014)\end{array}$ & $\begin{array}{c}0.016 \\
(0.017)\end{array}$ & $\begin{array}{l}-0.000 \\
(0.001)\end{array}$ & $\begin{array}{c}0.000 \\
(0.003)\end{array}$ & $\begin{array}{c}-0.005 \\
(0.006)\end{array}$ \\
\hline $\begin{array}{l}4 \text { years } \\
\text { pre-QRIS }\end{array}$ & $\begin{array}{l}-0.015^{*} \\
(0.008)\end{array}$ & $\begin{array}{c}0.003 \\
(0.013)\end{array}$ & $\begin{array}{c}0.014 \\
(0.014)\end{array}$ & $\begin{array}{c}0.002 \\
(0.002)\end{array}$ & $\begin{array}{l}-0.001 \\
(0.003)\end{array}$ & $\begin{array}{l}-0.009 \\
(0.007)\end{array}$ \\
\hline $\begin{array}{l}3 \text { years } \\
\text { pre-QRIS }\end{array}$ & $\begin{array}{l}-0.017 * * \\
(0.008)\end{array}$ & $\begin{array}{c}0.016 \\
(0.016)\end{array}$ & $\begin{array}{l}0.026 * \\
(0.015)\end{array}$ & $\begin{array}{c}0.002 \\
(0.001)\end{array}$ & $\begin{array}{l}-0.002 \\
(0.004)\end{array}$ & $\begin{array}{l}-0.002 \\
(0.007)\end{array}$ \\
\hline $\begin{array}{l}2 \text { years } \\
\text { pre-QRIS }\end{array}$ & $\begin{array}{l}-0.027 * * * \\
(0.009)\end{array}$ & $\begin{array}{c}0.012 \\
(0.019)\end{array}$ & $\begin{array}{c}0.014 \\
(0.017)\end{array}$ & $\begin{array}{c}0.002 \\
(0.002)\end{array}$ & $\begin{array}{l}-0.003 \\
(0.004)\end{array}$ & $\begin{array}{l}-0.007 \\
(0.007)\end{array}$ \\
\hline $\begin{array}{l}1 \text { year } \\
\text { pre-QRIS }\end{array}$ & $\begin{array}{l}-0.033 * * * \\
(0.010)\end{array}$ & $\begin{array}{c}0.025 \\
(0.016)\end{array}$ & $\begin{array}{c}0.019 \\
(0.016)\end{array}$ & $\begin{array}{l}0.004 * * \\
(0.002)\end{array}$ & $\begin{array}{c}0.002 \\
(0.004)\end{array}$ & $\begin{array}{l}-0.001 \\
(0.008)\end{array}$ \\
\hline QRIS & $\begin{array}{l}-0.025 * * \\
(0.011)\end{array}$ & $\begin{array}{l}0.056 * * * \\
(0.017)\end{array}$ & $\begin{array}{l}0.046 * * \\
(0.018)\end{array}$ & $\begin{array}{l}0.005 * * * \\
(0.002)\end{array}$ & $\begin{array}{c}0.006 \\
(0.004)\end{array}$ & $\begin{array}{c}0.005 \\
(0.009)\end{array}$ \\
\hline
\end{tabular}

Notes: Standard errors, which are adjusted for state-year clustering, are displayed in parentheses. All models include the state-level controls, state fixed effects, quarter*year effects, and state-specific linear time trends. $* * *, * *$, and * indicate statistical significance at the $0.01,0.05$, and 0.10 levels, respectively. 
Appendix Table 1: Summary of Outcome Variables, Datasets, and Estimation Approaches

\begin{tabular}{|c|c|c|c|c|}
\hline Outcome & Survey & Years & $\mathbf{N}$ & Estimation Method \\
\hline \multicolumn{5}{|c|}{ Panel A: Families' Child Care Choices and Maternal Employment } \\
\hline Family child care choices & $\begin{array}{l}\text { National Household } \\
\text { Education Survey (NHES) }\end{array}$ & 2005 and 2012 & 14,270 & Multinomial logit \\
\hline Hours per week of child care use & $\begin{array}{l}\text { National Household } \\
\text { Education Survey (NHES) }\end{array}$ & 2005 and 2012 & 14,270 & Tobit \\
\hline Pays for child care & $\begin{array}{l}\text { National Household } \\
\text { Education Survey (NHES) }\end{array}$ & 2005 and 2012 & 14,270 & OLS \\
\hline Log weekly and hourly amount paid for care & $\begin{array}{l}\text { National Household } \\
\text { Education Survey (NHES) }\end{array}$ & 2005 and 2012 & 14,270 & OLS \\
\hline Any maternal employment last year & $\begin{array}{l}\text { Current Population Survey } \\
\text { (CPS) }\end{array}$ & $1992-2015$ & 259,005 & OLS \\
\hline Weeks and hours of maternal work & $\begin{array}{l}\text { Current Population Survey } \\
\text { (CPS) }\end{array}$ & $1992-2015$ & 259,005 & Tobit \\
\hline Log hourly maternal wage & $\begin{array}{l}\text { Current Population Survey } \\
\text { (CPS) }\end{array}$ & $1992-2015$ & 259,005 & OLS \\
\hline \multicolumn{5}{|l|}{ Panel B: Child Care Labor Supply and Compensation } \\
\hline Child care sectoral choice & $\begin{array}{l}\text { Current Population Survey } \\
\text { (CPS) }\end{array}$ & $1992-2015$ & $1,365,519$ & Multinomial logit \\
\hline Log hourly child care worker wages & $\begin{array}{l}\text { Current Population Survey } \\
\text { (CPS) }\end{array}$ & $1992-2015$ & 47,431 & OLS \\
\hline Log number of employees per child ages $0-5$ & $\begin{array}{l}\text { Quarterly Workforce } \\
\text { Indicators (QWI) }\end{array}$ & $1993-2015$ & 3,639 & OLS \\
\hline Log number of new hires per child ages $0-5$ & $\begin{array}{l}\text { Quarterly Workforce } \\
\text { Indicators (QWI) }\end{array}$ & $1993-2015$ & 3,504 & OLS \\
\hline Log number of job separations per child ages $0-5$ & $\begin{array}{l}\text { Quarterly Workforce } \\
\text { Indicators (QWI) }\end{array}$ & $1993-2015$ & 3,632 & OLS \\
\hline Turnover rate & $\begin{array}{l}\text { Quarterly Workforce } \\
\text { Indicators (QWI) }\end{array}$ & $1993-2015$ & 3,492 & OLS \\
\hline Log real monthly earnings & $\begin{array}{l}\text { Quarterly Workforce } \\
\text { Indicators (QWI) }\end{array}$ & $1993-2015$ & 3,588 & OLS \\
\hline Log real new hires' monthly earnings & $\begin{array}{l}\text { Quarterly Workforce } \\
\text { Indicators (QWI) }\end{array}$ & $1993-2015$ & 3,543 & OLS \\
\hline
\end{tabular}

